\title{
The Monetary Origins of Asymmetric Information in International Equity Markets
}

\author{
Gregory H. Bauer* Clara Vega*
}

This version: March 22, 2004

\begin{abstract}
Previous studies using low frequency data have found that macroeconomic shocks contribute little to international stock market covariation. However, these papers have not accounted for the presence of asymmetric information where sophisticated investors generate private information about the fundamentals that drive returns in many countries. In this paper, we use a new microstructure data set to identify better the effects of private and public information shocks about US monetary policy and equity returns. High-frequency private and public information shocks help forecast domestic money and equity returns over daily and weekly intervals. In addition, these shocks are components of factors that are priced in a model of the cross section of international returns. Linking private information to an important economic fundamental is useful for many domestic and international asset pricing tests.
\end{abstract}

Keywords: Private information, international equity returns, monetary policy, foreign exchange rates, exchange traded funds.

\footnotetext{
${ }^{*}$ We thank Rui Albuquerque, Mike Barclay, Michael Fleming, Bill Schwert, Jerry Warner as well as participants at the Simon School of Business Brown Bag lunch for their comments. Bauer and Vega are affiliated with the William E. Simon Graduate School of Business Administration. Address: Carol Simon Hall, University of Rochester, Rochester, NY 14627. E-mail: bauer@simon.rochester.edu and vega@simon.rochester.edu. The usual disclaimer applies.
} 


\section{Introduction}

Identifying the causes of international stock market covariation remains a puzzling issue in finance. Asset pricing models dictate that expected stock returns vary in response to changes in risk-free interest rates, changes in expected future cash flows and/or changes in the equity risk premium. In a rational asset pricing framework, with international market integration, comovements in international stock returns would be driven by news about macroeconomic factors that affect cash flows, risk-free rates or risk premia in many countries.

However, existing studies using low-frequency data show that macroeconomic factors have a limited impact on international equity returns. For example, King et al. (1994) construct a factor model of sixteen national stock market monthly returns and examine the influence of ten key macroeconomic variables. They conclude that the surprise components of these observable variables contribute little to world stock market variation. Rather, there is a dominant unobservable (i.e. non-public) factor driving international returns. Karolyi and Stulz (1996) show that neither macroeconomic news announcements nor interest rate shocks significantly affect comovements between US and Japanese stock returns. Connolly and Wang (2002) examine the open-to-close equity market returns of the U.S., U.K., and Japan and find that foreign returns cause movements in domestic markets even after accounting for macroeconomic news announcements.

The poor performance of macroeconomic factors has motivated a search for market frictions that could explain international stock market comovements. Noise trader risk or other irrational phenomena have received most of the attention. For example, King et al. (1994) interpret the common factor that is unrelated to fundamentals as an index of "investor sentiment". 1

An alternative friction that could help explain international comovements is asymmetric information based trading. In the literature that examines the limits to international risk sharing, asymmetric information is used as a theoretical explanation of the "home bias" and "familiarity" puzzles in international portfolio selection. ${ }^{2}$ In contrast, the literature has been largely silent on the effects of private information based trading on international asset return covariability. When sophisticated agents trade, their private information is (partially) revealed to the market causing revisions in asset prices. Private information based trading could thus be a potential cause of the comovements in international stock returns if agents had superior knowledge about the common factors that price

\footnotetext{
1 See also King and Wadhwani (1990) and Lin et al. (1994).

2 Here sophisticated agents are believed to have superior ("private") information about the returns on assets in their own country. A broader definition of private information is given below.
} 
equities from many countries. However, the economic origins of such private information remain unexplored. Indeed, Goodhart and O'Hara (1997) wonder: "in the international context, how could private information be expected to have a global impact?".

In this paper, we provide an answer to this question. We start by providing empirical estimates of private information based trading in the US money and equity markets. Based on an analysis of microstructure data, we show that some agents have superior knowledge about both future US interest rates and aggregate US equity market returns. Private information based trades have a significant impact on money and equity market returns over holding periods ranging from one day out to a week.

Our interpretation of these results is that sophisticated investors appear to have good information about future macroeconomic factors that will affect both US equity prices and interest rates. If international equity markets are integrated then information about US factors will give informed agents superior knowledge about the global factors that price stocks in many countries (Albuquerque et al. (2003a)). It is then likely that the private information of the sophisticated investors trading in these (liquid) US markets will help explain the cross section of international equity returns.

We use a latent factor model of international equity returns to evaluate the effects of private information spillover across markets. The latent factors are composed of public and private information shocks from the US money and equity markets. We examine how these factors are related to daily and weekly returns on foreign equity markets. We show that private and public information shocks arising in US markets are components of priced factors in a model of the cross section of international equity returns. Sophisticated investors have an impact on global markets when their superior information is incorporated into international equity returns. To the best of our knowledge this is the first paper to show that private information is part of a priced factor in an international setting.

This paper extends the existing literature in three dimensions. The first extension is to adapt techniques from the microstructure literature (primarily Hasbrouck (1991)) to identify information shocks in aggregate stock and money markets from quote revisions and order flows sampled at high frequencies. These shocks can be orthogonalized into those due to private and public information. Using order flow sampled at high frequencies provides a powerful method of obtaining private information shocks (e.g. Hasbrouck (1991), Brennan and Subrahmanyam (1996), Madhavan, Richardson and Roomans (1997), Yu (2003)). Similarly, the effect of public news on asset prices can be measured more accurately using high-frequency data (Andersen et al. (2003)). We can use the high frequency shocks obtained from our time-series regressions as elements of the latent factors in a conditional asset pricing model of the cross section of international returns. The model 
reveals that the shocks are both statistically and economically important.

The second extension is to focus on shocks related to a specific macroeconomic fundamental: US monetary policy. Cochrane and Piazzesi (2002) and others have shown that unanticipated daily movements in short-term US interest rates are good proxies for monetary policy innovations. Cochrane and Piazessi (2002) also show that these public information shocks have a large impact on short and long-term US bond yields. We extend their work in two ways. First, using time series regressions on our microstructure data, we obtain both public and private information high-frequency shocks about US monetary policy. We then show that these shocks affect prices in the US equity market. Second, we show that the shocks have an affect on the cross section of international equity returns.

Our third extension is that instead of focusing on the returns of foreign stocks traded in national markets, we use foreign stock indexes that trade in New York as Exchange Traded Funds (ETFs). ETFs are bundles of foreign stocks that trade on the AMEX and are priced in US dollars. They are designed to be a low cost instrument that tracks a foreign stock index. As the supply of the ETF can be altered at any time, arbitrage ensures that its price closely tracks the index. By using these contracts, we observe returns and order flows on foreign equities that trade contemporaneously with their US counterparts. We can thus obtain high-frequency measures of public and private information shocks that affect the foreign indexes during US trading times.

One potential problem in previous low-frequency studies of international equity market comovements is non-synchronous trading. Those studies examined the impact of information events that occurred during US trading times on foreign (overnight) returns. The different time zones of the markets complicates the inference. ${ }^{3}$ In this paper, we avoid this problem by using foreign assets that trade contemporaneously with American stock returns and by focusing on public and private information shocks released during US trading times only. However, the foreign assets will respond to news released in the home markets as well. Thus our approach does not measure the effects of all private information based trades on the assets but only a subset of the trades. ${ }^{4}$

A potential problem with our approach is that the foreign indexes (ETFs) trade less

\footnotetext{
3 Low-frequency studies find conflicting results about causality. For example, Hammao, Masulis and $\mathrm{Ng}$ (1990), and King and Wadhwani (1990) find that correlations in volatility and prices appear to be causal from the United States to other countries. On the other hand, Lin, Engle and Ito (1994) find a bi-directional relationship between New York and Tokyo and Susmel and Engle (1994) find a bi-directional relationship, albeit weak, between New York and London. Engle, Ito and Lin (1990) find a bi-directional relationship in the intra-day yen/dollar exchange rate.

4 Craig et al. (1995) finds that trading in Nikkei futures in the US provides information about next-day Japanese equity returns. However, they do not identify the sources of the information.
} 
in the US market than they do in their home market. The potential for stale prices will complicate any short-run analysis of the returns. However, the focus in this paper is on changes in the foreign equity prices over holding periods ranging from a day out to a week. ${ }^{5}$ At these intervals, stale prices will have much less of an influence. An additional benefit of examining daily and weekly intervals is that we obtain the aggregate US and foreign market response to information released during US trading times. This is important as foreign market trading could negate the effects of information released during US trading times leaving no long-run impact on the price of the security. However, we find that our high-frequency information shocks that occur during US trading times continue to have an impact on foreign equity returns up to a week later.

Our focus on trading related to US factors helps to fill in the gaps from previous studies. Albuquerque et al. (2003a) identify a common global factor which accounts for approximately half of the variation in monthly trades by US investors due to private information. While they speculate on the origins of the private information they do not test any particular factor. Other papers have hinted that private information in one market may spill over into a foreign equity market. For example, Werner and Kleidon (1996) examine the intra-day patterns in trading volume, return volatility and bid-ask spreads of cross-listed stocks in the UK and US equity markets. After testing several hypotheses that could cause the patterns, they conclude that the private information revealed by US order flow is the main cause of the patterns. However, the paper does not indicate what the private information could be.

Our paper also has contributions for areas other than international asset pricing. One contribution is to the growing literature that attempts to link microstructure concepts such as private information and liquidity to asset pricing. ${ }^{6}$ Easley, Hvidkjaer and O'Hara (2002) find that a measure of a stock's probability of information based trading is priced in the cross section of US stocks. In this paper, we provide additional support for their analysis by showing that part of the private information in the US equity market is related to a specific macroeconomic fundamental.

We proceed as follows. In section 2 we describe the data and show how our interest rate series is related to US monetary policy. In section 3 we describe our general microstructure model for extracting private and public information shocks from the US money and equity markets. In section 4 we present our latent factor model and show that private information is a priced factor in the cross section of international equity returns.

\footnotetext{
5 We construct the daily and weekly returns using overlapping samples of high-frequency data. This allows us to maintain the identification advantages of a microstructure analysis while focusing on the information content of longer holding period returns.

6 This literature is surveyed in Easley and O'Hara (2002).
} 
We conclude in section 5.

\section{Data Description and US Monetary Policy Proxies}

This section starts by explaining the sources of our data series. It also explains how to obtain signed trades (order flow) from the Eurodollar, US equity and foreign equity markets. We then show how prices in the Eurodollar futures market are related to changes in US monetary policy.

\subsection{Data description}

In order to capture public and private information shocks in the US and foreign equity markets, we use high-frequency data on Exchange Traded Funds (ETFs). ETFs are shares of a portfolio of stocks that trade continuously on an exchange and are designed to track closely the performance of a specific index. ${ }^{7}$ Managers of the ETFs may buy either all the stocks in the index or a sample of stocks to track the index. It is important to emphasize that ETFs are not closed-end funds. Closed-end funds offer a fixed supply of shares, and as demand changes they frequently trade at appreciable discounts from (and sometimes premiums to) their net asset values (NAVs). In contrast, market participants are able to create and redeem shares in an ETF when its market price differs from the value of its underlying index. This ability to open the funds at any time ensures that ETFs trade near their NAVs. ${ }^{8}$

The US ETF is the S\&P 500 fund (SPDR or "Spider") which began trading on the AMEX in 1993. ${ }^{9}$ Elton et al. (2002) discuss the investment and tracking performance of this fund. They conclude that the SPDR closely tracks the S\&P 500 index as the difference between the two is less than 1.8 basis points per annum. The SPDR is a very liquid security; in mid-2003, the fund had over US 37 billion dollars in assets under management with average daily trading volume totalling US 4 billion dollars.

The foreign ETFs are shares of portfolios designed to track the performance of foreign market indexes compiled by Morgan Stanley Capital International (MSCI). They were launched under the World Equity Benchmark Shares (WEBS) brand and were renamed in 1998 as "iShares" or Index Shares. They are managed by Barclays Global Fund Advisors and trade on the AMEX. We use bid quotes, ask quotes and transactions prices for the

\footnotetext{
$7 \quad$ All the ETFs we use are listed on the American Stock Exchange (AMEX); some of them are listed on other exchanges, including foreign exchanges. Nevertheless, the largest traded volume for these assets takes place in AMEX, and we confine ourselves to data from this exchange.

8 Another advantage of ETFs is their tax efficieny. See Elton et al (2002)

9 The SPDR began trading on the NYSE also on July 31, 2001.
} 
ETFs of the US and twelve foreign countries (Germany, Japan, UK, Switzerland, Canada, France, Netherlands, Hong Kong, Spain, Sweden, Australia and Italy). We select these countries as they have developed equity markets and ETF data that are available over our sample period.

The US and foreign ETF data were obtained from the Trades and Quotes (TAQ) database. The sample period consists of continuously-recorded tick-by-tick data from April 1, 1996 to November 30, 2001 (1,206 days). To calculate ETF buyer-initiated orders and seller-initiated orders we use the algorithm developed by Lee and Ready (1991). ${ }^{10}$ Order flow is the net amount of buyer-initiated less seller-initiated trades.

In order to estimate public and private information shocks in the US money market, we use high-frequency data on the Eurodollar futures contract that trades on the Chicago Mercantile Exchange (CME). ${ }^{11}$ The Eurodollar contract is considered to be the most liquid exchange-traded money-market instrument in the world. The contract is valued at 100 less the London Inter-Bank Offer Rate (LIBOR) on Eurodollars at maturity. We examine five different maturities: the three-month, six-month, nine-month, one-year, and five-year $(k=3,6,9,12$, and 60$)$ contracts. The contracts maturing in less than one year are the most liquid.

The CME records "time and sales data" which contain the time and price of a transaction only if the price is different from the previously recorded price. Bid and ask quotes appear in this file only if the bid quote is above (the ask quote is below) the previously recorded transaction price. Because quotes are generally not recorded we use the "tick test" to estimate buyer-initiated and seller-initiated orders. ${ }^{12}$ The order flow series that we use is the net purchases (buyer-initiated less seller-initiated trades).

Using time and sales data produces two opposing effects on our measure of private information. The first effect is that we are underestimating the number of "liquidity trades" as opposed to "informed trades". As we have time and sales data, we can measure trades only when the price of the asset changes which is more likely to occur

\footnotetext{
10 This algorithm compares transaction prices to the mid-quote five seconds before the transaction took place. If the transaction price is above the mid-quote then we classify the trade as a buy; if the transaction price is below the mid-quote we classify the trade as a sell. If the transaction price is equal to the mid-quote then we use the tick test. Ellis, Michaely and O'Hara (2000) evaluate how well the Lee and Ready algorithm performs and find that it is $81.05 \%$ accurate.

11 We could have also used federal funds futures contract data. We use the Eurodollar futures contract because it is more liquid than the fed funds futures contract implying that it may reflect information about the state of the economy better. We use futures market data as there is no highfrequency transactions data available in the spot market.

12 The tick test is: if the transaction price is higher than the previous price we classify the trade as a buy and if it is below the previous transaction price we classify it as a sell. Ellis, Michaely and O'Hara (2000) find that the tick test correctly classifies $77.6 \%$ of the trades.
} 
due to an informed trade rather than a liquidity based trade. Thus, we systematically underestimate liquidity based trades. This implies that our order flow series is dominated by information based trading.

The second effect comes from not being able to observe quotes which forces us to classify trades using the tick test. Our estimated order flows for the Eurodollar data using the tick test will be noisier than the order flow measure for the other assets which we obtain by using the Lee and Ready algorithm. However, Ellis, Michaely and O'Hara (2000) show that the tick test does not induce a systematic bias into the resulting order flow data.

The foreign ETFs trade in US dollars. As a robustness check to our results below, we wish to evaluate the effect of our public and private information shocks on foreign equity returns measured in foreign currencies. Unfortunately, we are unable to obtain high-frequency quote and transaction data on the spot market foreign exchange rates associated with our twelve foreign countries. We therefore use currency future contracts traded on the CME. We obtain time-and-sales data for the Euro, Japanese Yen, UK Pound, Swiss Franc and Canadian dollar futures contracts. ${ }^{13}$ The contracts are priced in US dollars per unit of foreign currency. Again we use the tick test to categorize the transactions data as purchases or sales. We use the three-month futures contracts as these are the most liquid.

One difficulty with combining our various data series is that the markets that we analyze have slightly different trading times. The Eurodollar and foreign currency futures contracts trade on the CME where the trading hours are from 8:20 a.m. to 3:00 p.m. EST. The ETFs trade on the AMEX where the trading hours are from 9:30 a.m. to 4:00 p.m. EST. In our analysis, we constrain the aggregate data set to a common time period. We also divide the trading day into subperiods to determine the influence of one market on the other. We therefore divide the day into eleven 30-minute intervals with the first interval starting at 9:30 a.m. EST and last interval ending at 3:00 p.m. EST. This results in a total of 15,598 half-hour observations for the entire data set. We use the last mid-quote recorded during each half-hour interval as our price. ${ }^{14}$ Quote revisions are the log differences of these prices. Signed order flow is the total number of purchases less the total amount of sales during the interval.

Another difficulty with the data set is that the trades and quote revisions display

\footnotetext{
13 As in Fair (2003), the Euro futures contract series is the German Deutsche Mark futures contract prior to June 1, 1999 and the Euro futures contract after that. Both contracts traded somewhat before and after this date, but this date is a reasonable splicing date because liquidity started to switch from the German Deutsche Mark market to the Euro market.

14 For the Eurodollar and foreign currency futures contracts we use the last transaction price recorded during the interval.
} 
an intra-day seasonality. We therefore perform an initial deseasonalization by projecting the order flows and quote revisions data on time-of-day dummy variables and use the mean-centered residuals as our basic data series.

Sample statistics for the quote revisions on the Eurodollar futures contracts, the US and foreign ETFs and the foreign currency futures contracts are given in Table 1a. The Eurodollar futures contracts have a very small average mean return and a low standard deviation relative to the other series. The contracts with maturities of less than one year are very liquid with almost all intervals recording a quote (transaction price). The ETFs are much more volatile with standard deviations above 0.2 per cent per half hour of trading for all countries. The US ETF (Spider) is very liquid with observations recorded in 99.7 per cent of all intervals. The foreign ETFs are naturally less liquid with some contracts having quote observation in only 40 per cent of the intervals. This may complicate the short-horizon analysis of returns; however, our daily and weekly holding periods makes this issue much less important. The foreign currency contracts are all liquid.

Table 1b shows the sample statistics of the order flow data for the assets. These data are displayed in numbers of net purchases per half-hour period. For example, the 3-month Eurodollar futures contract has an average of 0.029 contracts purchased net each half hour during the sample period. As can be seen the net number of contracts traded each interval ranges widely for the Eurodollar contracts, the US ETF and the foreign currency futures contracts indicating a fair degree of trading activity. ${ }^{15}$ Some of the foreign ETFs trade much less frequently with trades recorded in approximately 20 per cent of all the intervals. This will complicate the analysis below only when we wish to examine the impact of country-specific private information on the foreign returns. We obtain the global private information shocks from trading in the Eurodollar and US ETF markets, both which are quite liquid.

Table 2a presents the contemporaneous correlations between the quote revisions on the assets. The top part of the table shows the correlations between the Eurodollar futures, the US ETF and the foreign currency futures contracts. There is a high degree of correlation between price movements on the short-dated Eurodollar futures contracts. The negative correlation between the US ETF quote revision and those on the Eurodollar contracts implies that price gains in the US ETF are associated with rising Eurodollar interest rates. In our sample, the Fed raised interest rates as the equity market was gaining, then lowered rates as the market declined. The correlations with the foreign currency contracts indicate that an increase in the US equity market is associated with a strengthening US dollar against all of the foreign currencies except the Canadian dollar.

\footnotetext{
15 The frequency of observations recorded for the Eurodollar and foreign currency contract data are the same for both the quotes and order flows for the series due to the use of time-and-sales data.
} 
The correlations among the US and foreign equity quotes at the bottom part of the table indicate that common factors are affecting the returns on these assets during US trading times.

The net purchases data also display common variation though the correlations are not as high (Table 2b). Again the short-dated Eurodollar contracts display common variation. Investors purchase Eurodollar contracts when they are selling the US equity market as shown in the middle of the table. The bottom part of the table indicates some common variation to net purchases across the ETF markets.

In our analysis below, we study the effects of information shocks arising in the US money and equity markets on foreign equities. This implies a causal (time series) relation that we should establish first. We thus undertake a number of Granger causality tests. In the first set of tests, we examine whether foreign equity market order flows and quote revisions cause either the US money or equity markets. In these tests we regress the order flow in the US money or equity market on 12 lagged values of order flow and quote revisions in the market. ${ }^{16}$ We also include 12 lagged values of the foreign ETF order flows and quote revisions and see if the coefficients are jointly significant yielding a test statistic that is distributed as $\chi^{2}(12)$. We repeat the same test for the US money and equity markets quote revision regressions.

Table 3a presents the asymptotic marginal significance levels ( $P$-values) of the tests. A small value would indicate predictability of the foreign equity market variable for the US order flow or quote revisions. Only seven out of the 96 statistics are significant at a 5 per cent level indicating that the neither the order flows nor quote revisions from the foreign ETF markets Granger-cause either the Eurodollar or US ETF market.

We also undertake similar tests of the reverse causality; i.e. we test whether the US money and equity markets Granger-cause the foreign equity markets. Table $3 \mathrm{~b}$ presents the results. Lagged order flow in the Eurodollar and US ETF markets is a significant predictor of future quotes and order flows in a number of countries. Lagged quote revisions in the Eurodollar and US ETF markets yield a large amount of predictability in the foreign ETF order flow processes. Investors who transact in US trading times appear to base their foreign buying decisions on recent price movements in the US markets. There is also a strong relationship in the foreign quote revision regressions. ETF market makers respond to lagged order flows and quote revisions in the two US markets when they set their quotes.

The tests indicate that "price discovery" occurs in the US money and equity markets and that this information is impounded into foreign equity prices. This is related to the

\footnotetext{
16 We use 12 lagged values to capture the effects of a full day of trading. Our results are robust to this choice.
} 
liquidity of the markets. When investors receive private news about "global" factors (i.e. factors that affect many asset markets) they undertake transactions in those markets that are the most liquid. Thus the initial price response in the Eurodollar and US ETF markets may simply result from the relative liquidity of the markets. The market makers in the less liquid market observe these prices and adjusts their quotes when it is optimal to do so.

\subsection{The Eurodollar futures contract and US monetary policy}

How to measure monetary policy innovations remains a contentious subject in the literature. One approach is to use changes in interest rates as proxy variables for market expectations of changes in future monetary policy. Cochrane and Piazzesi (2002) show that the (spot) Eurodollar interest rate can successfully forecast moves in the Federal funds target rate, the primary instrument of US monetary policy. They note that interest rate based forecasts have a number of advantages over the traditional approach of modeling Fed rate changes by a vector autoregression (VAR). These include the ability of interest rate based forecasts to avoid the omitted variables problem of a VAR approach as the market summarize the vast amount of information used by the Fed. They also overcome the problem of time varying parameters faced by modeling based approaches as the market adapts to perceived changes in the Fed's reaction function. ${ }^{17}$

In Figure 1 we show how the price of the six-month Eurodollar futures contract is related to future Federal funds target moves. From June 1999 to June 2000, the Eurodollar futures lead the Fed funds target rate increases. Likewise, from November 2000 to November 2001, the Eurodollar futures lead the target rate decreases. In the earlier part of the sample, from April 1996 to June 1999, there are two "false" predictions, but for the most part the Eurodollar futures correctly predicts no changes in the target and leads the increase and decrease in the target rate.

To formalize how well the Eurodollar futures contract can forecast target rate changes, we estimate the forecasting model of Cochrane and Piazzesi (2002). Here we estimate the model in price form; i.e., we calculate a "price" for the Fed funds target-rate as $P_{\tau}^{T R}=\log \left(100-T R_{\tau}\right)$, where $T R_{\tau}$ is the target-rate at time $\tau$. We do this to be consistent with our public and private information system of equations used below, which are in quote revision form. The forecast regression is then

$$
\Delta P_{\tau}^{T R}=a+b P_{\tau-1}^{T R}+c S P_{j \tau-1}+\varepsilon_{j \tau},
$$

\footnotetext{
17 Following the same logic, other papers have used fed funds futures data to forecast target-rate changes (Rudebusch (1998), Kuttner (2001), Carlson, McIntire and Thomson (1995) among others). We use the Eurodollar futures contract as it is much more liquid.
} 
where: $\Delta P_{\tau}^{T R}=P_{\tau}^{T R}-P_{\tau-1}^{T R}$ is the "return" on the target rate at time $\tau$, when a target-rate change is announced; $P_{\tau-1}^{T R}$ is the target-rate 30 -minutes before the announced target-rate change; and $S P_{j \tau-1}=P_{\tau-1}^{T R}-\log \left(P_{\tau-1}^{E D}\right)$ is the spread between the log targetrate price and the log Eurodollar futures price on the $j$-month contract also recorded 30 minutes before the target-rate change. Note that the time index $\tau$ is an event time index. In our sample period there are twenty target-rate changes, so $\tau=1, \ldots, 20$.

We run the Cochrane-Piazzesi regression separately using each of the Eurodollar futures contracts. The results are shown in Table 4 . The six-month contract has the highest predictive power with an $R^{2}$ of 0.920 . The negative coefficient on the spread is to be expected; if the "price" of the target rate is above that on the Eurodollar contract, the negative coefficient indicates that a decrease in the Fed funds price is forecast so that it moves closer to that of the Eurodollar contract. Overall, the regressions indicate that the spread between the Eurodollar futures contracts and the current level of the target contain significant information about future Fed funds target changes.

\section{Private Information in US Asset Markets}

In this section we use microstructure theory and a modification of a standard empirical model to obtain measures of private and public information shocks in the US money and equity markets. ${ }^{18}$ We start by outlining our general modeling approach and then apply it to the US money and equity markets. The model yields public and private information shocks from the two markets that are used in the cross-sectional analysis of international stock returns in the next section. However, they are also of interest in their own right for revealing the impact of private information based trades in aggregate US markets.

\subsection{General modeling approach}

Theoretical papers designed to explain price changes in a microstructure setting have emphasized two factors: the optimal inventory level of the specialist and the response of the quote to information revelation. Our approach is to focus on the information revelation component while controlling for inventory and liquidity effects. Figure 2 presents the stylized timing convention that is present in the models. Here, an investor observes the original quotes ( $q_{t-1}^{b}$ is the bid, $q_{t-1}^{a}$ is the ask) set by the market maker at time $t-1$. The investor then decides on her trade (i.e. net order flow) $x_{t}$ which is driven partially

\footnotetext{
18 See O'Hara (1997) for a discussion and derivation of domestic microstructure models. For a discussion and derivation of international microstructure models, see Lyons (2001). For a survey on empirical time series microstructure models see Hasbrouck (1996).
} 
by private information and by liquidity needs. Public information news arrives after the trade is completed and the market maker sets new quotes at time $t$, prior to any new trades being completed.

To estimate the public and private information shocks in a particular asset market, we adopt the linear vector autoregression of Hasbrouck (1991). As he points out, many microstructure imperfections (e.g. inventory control effects, price discreteness, exchange mandated price smoothing) can cause lagged effects in order flow and quote revision dynamics. We therefore model investor order flow as a linear function of past flows and quote revisions:

$$
x_{t}=c+\theta(L) r_{t}+\kappa(L) x_{t}+v(x)_{t},
$$

where: $x_{t}$ is the (net) order flow in the market; $r_{t}$ is the quote revision on the asset; and $\theta(L)$ and $\kappa(L)$ are polynomials in the lag operator. The residual in this equation $\left(v(x)_{t}\right)$ includes two components. The first is unanticipated trades due to liquidity shocks: investors will undertake trades in an asset market in response to random shocks to their wealth. The second component is unanticipated trades due to new private information: investors will undertake trades when their private assessment of the asset's value is different from the prevailing market quote.

Quote revisions can be modeled using a similar autoregressive structure:

$$
r_{t}=c+\gamma(L) r_{t}+\delta(L) x_{t}+\lambda v(x)_{t}+v(r)_{t} .
$$

The lagged quote revision and order flow variables are also present here to capture transient microstructure effects. Note that contemporaneous unanticipated trades $\left(v(x)_{t}\right)$ are included in this equation given the assumption about information revelation in microstructure time outlined above. As the explanatory variables account for microstructure effects and private information, the disturbance $v(r)_{t}$ reflects public information news. The combined system of (2) and (3) thus provides two (orthogonal) shocks that represent private and public news in an asset market, respectively.

In this system, a private information shock will cause a sequence of quote revisions as the information becomes absorbed into the market price. The key difficulty is in identifying the private information component of the (unanticipated) trade $\left(v(x)_{t}\right)$. The identifying assumption is that in a market with informed and uninformed traders, order flow conveys information and therefore causes a persistent impact on the security's price. ${ }^{19}$ Liquidity or inventory based trades have no information value and thus have

19 Standard microstructure theory models with this set up include: Kyle (1985), as an example of an auction or batch strategic trading model; and Glosten and Milgrom (1985) and Easley and O'Hara 
only a transitory impact on prices. Thus we follow Hasbrouck (1991) and assume that with the passage of time, all rational agents expect quotes to revert (on average) to the fair value of the security,

$$
\text { as } s \rightarrow T, E\left[\left(q_{s}^{b}+q_{s}^{a}\right) / 2-p_{T} \mid \Phi_{t}\right] \rightarrow 0,
$$

where $s$ is some future time, $T$ is the terminal time when the true value of the security, $p_{T}$, is revealed, and $\Phi_{t}$ is the current (time $t$ ) information set. Private information about an asset's value will cause a change in the fair value of the security as the information is revealed though trading and becomes incorporated in the market's expectation of the price. To calculate the effect of a private information shock on an asset's price, we calculate the long-run impact that unanticipated trade orders have on the security's quotes.

To measure the permanent effects of an unanticipated trade, we construct the change in the (log) price of the asset over holding period $H$ :

$$
r_{t, t+H} \equiv \log \left(P_{t+H}\right)-\log \left(P_{t}\right)
$$

We can then model the $H$-period return using the same structure as above:

$$
r_{t, t+H}=c+\gamma(L) r_{t}+\delta(L) x_{t}+\lambda v\left(x_{t}\right)+v(r)_{t} .
$$

In this equation, the holding period return is driven in part by private information "news" that has been revealed to the market in the form of unanticipated trades $\left(v\left(x_{t}\right)\right)$. These unanticipated trades are noisy measures of private information because they include liquidity or inventory effects. The key economic identification that we obtain from the microstructure literature is that liquidity effects are transient while information effects are permanent. The trades will represent private information if the $\lambda$ coefficient is statistically significant for longer holding periods.

Our econometric specification is similar to Hasbrouck (1991) in that a reduced form specification for trades are used to obtain a residual that is a noisy measure of the private information news. He uses impulse response functions to obtain the impact of an unanticipated net purchase on total quote revisions over the next 20 trading intervals. This is a relatively short period compared to our approach which looks at the effect on cumulative returns over the next week. Our method has direct tests of the private information effects on returns via an examination of the significance of the $\lambda$ coefficient. Our approach provides robust standard errors on the impact of unanticipated trades on returns, something that is not easily available in a reduced form VAR with simultaneous variables on the right hand side.

(1987), as examples of sequential trade models. 


\subsection{Private and public information in US money and equity markets}

In this section, we present our model of net purchases and quote revisions in the Eurodollar futures and US ETF markets. While we base our model on the general approach of the previous section, there are two additional issues that we must face. The first is that we are estimating the dynamics of quote revisions and order flows in the US money and equity markets simultaneously. An assumption is therefore required about the information sets of the market makers in the two markets. We assume that the market makers in both markets can observe past order flows and prices from both markets. ${ }^{20}$ In this way, private information shocks in one market may be transmitted to the other market.

The second issue is the assumed variance-covariance stationarity of the data needed to estimate the VAR, which is clearly not the case with the Eurodollar futures contract. ${ }^{21}$ Figure 1 shows that the mean of the Eurodollar rate changes over time as it fluctuates around the Fed funds target rate. We therefore model the conditional mean of the Eurodollar rate as a function of the Fed funds target rate.

Following our general approach above, the first equation in the system models the time-series process of the order flow in the Eurodollar futures market $\left(x_{t}^{E D}\right)$,

$$
x_{t}^{E D}=c+a(L) r_{t}^{E D}+b(L) x_{t}^{E D}+c(L) r_{t}^{U S}+d(L) x_{t}^{U S}+g P_{t-1}^{T R}+h S P_{t-1}+v(x)_{t}^{E D} .
$$

In this equation, net purchases in the Eurodollar futures market are linear functions of past net purchases and quote revisions in both the Eurodollar and US ETF markets. Current trades are a function of these public information variables due to various microstructure effects which in our setting may have an influence across several markets. We also include the two "monetary policy" variables that were used in the CochranePiazzesi target rate regressions: the price of the lagged Fed funds target rate $\left(P_{t-1}^{T R}\right)$ and the spread between the log target-rate price and the log Eurodollar futures price $\left(S P_{t-1}=P_{t-1}^{T R}-\log \left(P_{t-1}^{E D}\right)\right)$. Recall that both variables were shown to have good explanatory power for forecasting future Federal Reserve policy moves in Table 4. If agents trade in the Eurodollar market in anticipation of future Fed moves, these variables should help capture those effects.

\footnotetext{
20 We are assuming that sophisticated investors will trade on their superior knowledge of macroeconomic factors in several liquid markets simultaneously. Market makers would realize this and use as many sources of information as possible to reduce the information asymmetry. They can see aggregate trading activity in other asset markets and infer the signs of the recent trades from the cross-section of contemporaneous volume and price data.

21 In the steady-state of this system, information shocks would be absent and inventories would be at desired levels. Expected returns are constant and prices are thus a martingale.
} 
The order flow process for the US ETF can be modeled similarly:

$$
x_{t}^{U S}=c+a(L) r_{t}^{E D}+b(l) x_{t}^{E D}+c(L) r_{t}^{U S}+d(L) x_{t}^{U S}+g P_{t-1}^{T R}+h S P_{t-1}+v(x)_{t}^{U S} .
$$

Equity market order flow is also a function of past order flow and quote revisions in the two markets. ${ }^{22}$ If sophisticated investors trade in the equity market in anticipation of interest rate changes by the Federal Reserve, then the monetary policy variables from the Cochrane-Piazessi regressions should help capture this. The first two equations provide residuals that contain the private information of sophisticated investors in the money and equity markets.

The third equation in the system models the quote revision process in the US money market:

$$
\begin{aligned}
r_{t, t+H}^{E D}= & c+\theta(L) r_{t}^{E D}+\varphi(L) x_{t}^{E D}+\omega(L) r_{t}^{U S}+\eta(L) x_{t}^{U S}+\phi P_{t-1}^{T R}+\psi S P_{t-1} \\
& +\lambda_{E D} v(x)_{t}^{E D}+\lambda_{U S} v(x)_{t}^{U S}+v(r)_{t}^{E D} .
\end{aligned}
$$

In this equation, the holding period return on a Eurodollar futures contract is a function of past quote revisions and order flows in the two markets. These may have an influence over short holding periods as microstructure effects are important. As the holding period lengthens, these variables are less likely to have an influence. We also include the monetary policy variables in this regression for the reasons given above. The close relationship between the Eurodollar and target rates implies that the spread variable may help to capture the movement of the rates towards each other.

Quote revisions are also driven in part by private information "news" that has been revealed to the market in the form of unanticipated trades in both the money and equity markets $\left(v(x)_{t}^{E D}\right.$ and $v(x)_{t}^{U S}$, respectively). These unanticipated trades are noisy measures of private information because they include liquidity or inventory shocks. As stated above, the key economic identification that we obtain from the microstructure literature is that liquidity shocks are transient while information shocks have a permanent effect on the price of the asset. To measure the permanent effects of information shocks, we look at quote revisions in the Eurodollar futures over holding period $H$ :

$$
r_{t, t+H}^{E D} \equiv \log \left(P_{t+H}^{E D}\right)-\log \left(P_{t}^{E D}\right),
$$

where $P_{t}^{E D}$ is the price of the Eurodollar futures contract. ${ }^{23}$ Thus the trades will represent private information if the $\lambda_{E D}$ or $\lambda_{U S}$ coefficients are significant for longer holding periods.

\footnotetext{
22 The coefficients in (8) are different from those in (7). The symbols are the same as we do not wish to increase the notational burden.

23 Under our assumption (4), this is equivalent as time progresses to the return on a buy-and-hold strategy over $H$ periods in a Eurodollar futures contract. Note that a one-period return $r_{t, t+1}^{E D}$ represents the change in the price of the contract over a half-hour interval.
} 
We can gauge the effect of public and private information on US equity returns similarly via:

$$
\begin{aligned}
r_{t, t+H}^{U S}= & c+\theta(L) r_{t}^{E D}+\varphi(L) x_{t}^{E D}+\omega(L) r_{t}^{U S}+\eta(L) x_{t}^{U S}+\phi P_{t-1}^{T R}+\psi S P_{t-1} \\
& +\lambda_{E D} v(x)_{t}^{E D}+\lambda_{U S} v(x)_{t}^{U S}+\varsigma v(r)_{t}^{E D} \cdot 1(\Delta T R \neq 0)+v(r)_{t}^{U S} .
\end{aligned}
$$

In this regression, cumulated US equity returns over holding period $H\left(r_{t, t+H}^{U S} \equiv \log \left(P_{t+H}^{U S}\right)-\right.$ $\left.\log \left(P_{t}^{U S}\right)\right)$ are a function of past public information originating in the US money and equity markets. Current money market information will cause movements in equity returns under our assumption of interest rates being the fundamental variable. Unanticipated money and equity market order flows will forecast future equity returns if they contain private information that is relevant to the equity market maker. As in our money market analysis, the key test is that the unanticipated money and equity market trades have an effect on returns over longer holding periods $(H>1)$.

The half-hour $(H=1)$ version of the money market quote revision regression (9) provides an estimate of the expected change in the price of the Eurodollar contract. The residual from this regression $\left(v(r)_{t}^{E D}\right)$ will be the unexpected change in interest rates due to public news innovations. We can further decompose this residual using dummy variables into those shocks that occur when there is a Federal funds target rate change $(1(\Delta T R \neq 0))$ and when there is not $(1(\Delta T R=0))$. When the Federal Reserve changes interest rates, there is a clear causal chain from the money market to the equity market. Thus, the change in the price of the Eurodollar contract during these particular half-hour periods $(1(\Delta T R \neq 0))$ provides a high-frequency counterpart to the monetary policy shocks constructed by Cochrane and Piazzesi (2002). We therefore include these residuals in the equity market order flow regression. ${ }^{24,25}$

24 Conventional measures of standard errors from this system are likely to be understated due to two problems. The first is that extending the holding period of the asset out to $H$ periods will result in a moving-average error process in (9) and (10). The second problem is that the residuals in our intra-day data are likely to be heteroskedastic in line with other microstructure studies. We therefore report all results using Newey-West (1987) standard errors with a lag length equal to the minimum of $H-1$ or 12 half-hour trading intervals.

25 It is important in our specifications to ensure that our measures of private information have all of the effects of lagged public information removed from them. This means that instead of using a statistical criterion (such as AIC or SIC) to choose the optimal lag length $L$, we choose large lag lengths that are likely to be longer than those mandated by a statistical test or casual economic reasoning. We thus choose a lag length equal to just over one day of trading (12 half hour intervals) for our base case analysis. 


\subsection{Results}

Table $5 \mathrm{a}$ presents results of the first two equations from the model. The estimate of the Eurodollar order flow regression is at the top. Overall, the instruments do a poor job in capturing expected Eurodollar order flow as the $R^{2}$ statistic is only $0.006 .{ }^{26}$ The monetary variables are not significant suggesting that traders do not position themselves around monetary policy changes. However, this result may be misleading as these trades could occur at any time and thus trying to capture them with one lagged value may not be sufficient. The second regression is for US equity market order flow. This regression has an adjusted $R^{2}$ statistic of 0.068 indicating that the instruments have some ability to forecast next period's order flow. The sums of the US ETF lagged order flow and quote revision coefficients are significant as are the lagged Eurodollar quote revisions. The spread variable is also significant with a positive coefficient.

The poor ability of the selected instruments to capture order flow variation raises concern about the use of the residuals from these regressions in the holding period return regressions (9) and (10). The low degree of explanatory power indicates that the instruments are not able to capture much of the short-run inventory dynamics that are present in the markets. The residuals will therefore contain more of these short-run dynamics making them noisier signals of the long-run information component. This, in turn, makes our subsequent findings of significant information effects more conservative.

Table 5b shows the results of estimating the holding period returns (9) on the Eurodollar futures contract over periods ranging from one-half hour to five trading days. The ability of the selected instruments to model short-run movements in Eurodollar quote revisions is very high with the half-hour regression having an $R^{2}$ statistic of 0.752 . As the holding period lengthens, the statistics decrease rapidly in line with similar estimates of daily and weekly returns throughout the asset pricing literature. The spread variable is significant at conventional levels for all of the holding periods. When the spread is higher, the regressions in Table 4 showed that the price of the target asset was expected to fall (an increase in the target rate was likely). Here the spread shows that a decrease in the Eurodollar price (an increase in the Eurodollar rate) is also likely.

The regressions also include the unanticipated order flows from the money and equity markets (i.e. the residuals from the order flow regressions in Table 5a). The Eurodollar order flow variable is significant at all holding periods indicating that private information based trades are present in the Eurodollar futures market. Sophisticated agents appear

26 Throughout the paper, the $R^{2}$ statistics are adjusted for degress of freedom. The low degree of explanatory power is similar to estimates of order flow in other asset markets. For example, Hasbrouck (1991) obtains an $R^{2}$ of 0.086 estimating order flow of an individual stock. 
to have superior information about the direction of future interest rates. When they trade, the information becomes incorporated into market rates. The market makers do not appear to use equity market order flow for longer-run pricing decisions.

Table 5c presents the estimates of the holding period returns on the US ETF. As with the quote revision regressions, the half-hour holding period returns display a large amount of predictability with an $R^{2}$ statistic of 19.8 per cent. As the holding period lengthens, the degree of linear predictability again naturally falls. Neither of the two monetary policy variables from the Cochrane-Piazzesi regressions are significant. Rather, the influence of the money market is captured by the information shocks from the Eurodollar market. Unanticipated money market order flow is significant for the half-hour to 1 day holding periods. This gives some support to a private information spillover from the US money market to the US equity market. The unexpected change in the price of the Eurodollar contract when there is a Federal Reserve policy change $\left(v(r)_{t}^{E D} 1(\Delta T R \neq 0)\right)$ is significant at a 5 day holding period horizon. ${ }^{27}$ The negative coefficients on both the private and public information shocks are in line with the unconditional negative correlation coefficients shown in Table 2.

The last column in the table shows the effect of unanticipated equity market purchases over a half-hour period on future equity returns. The coefficients are positive and significant for all of the holding periods examined. While this variable may reflect both liquidity and information shocks at short horizons, only the information based component will have an effect over longer holding periods. It is clear then that sophisticated investors have private information about the aggregate US equity market. When they trade, this information is gradually incorporated into prices.

\subsection{Interpretation}

Our view of asymmetric information is different from the standard one where traders have good information about a specific firm. One way to view the equity market results in this section is that traders have correlated private information about many firms. While correlated private information has been examined in the theoretical works of Subrahmanyam (1991) and Chan (1993), they are silent on the economic origins of the information.

Our contribution is to relate aggregate private information to factors which influence the returns on many assets, in particular monetary policy. We have shown that unanticipated changes in the Fed Funds target, a public news shock, affects U.S. stocks. ${ }^{28}$ In

\footnotetext{
27 It is likely that the relatively small number of policy innovations in our data set (20) makes it difficult to determine the statistical significance of the effect, except at longer horizons.

28 While monetary policy is one of the factors influencing prices, there are likely to be many others. See Andersen et al. (2003) for an analysis. Other papers that find a significant influence of monetary
} 
addition, we have shown that private information originating in the US money markets also forecasts stock returns. ${ }^{29}$ We note that this private information is not "insider" information; rather it is the superior interpretation of public signals. The expense devoted to "Fed watching" by many financial institutions suggests that forecasting Federal Reserve actions is a profitable activity. Fed watchers (or the agents who use their analyses) can thus be viewed as informed traders whose orders convey information.

Saar (2001) notes that the price impact of trades may not be the result of superior knowledge of the cash flows on the assets being released to the market. Rather, it may be the result of the market maker assessing the distribution of demand in a heterogeneous investor environment. The market maker uses trades to obtain more information about investor preferences and endowments. In an empirical investigation of trade impact measures, Saar and Yu (2002) find that the permanent impact of trades does not relate to future firm earnings.

Given these findings, we remain agnostic as to whether the private information we find is about either the cash flows on the assets or how these cash flows will be demanded by market participants. Sophisticated investors could obtain superior knowledge of factors that affect the cash flows that US equities are claims to or future interest rate levels from macroeconomic analysis. Alternatively, they could obtain knowledge of future investor order flow in the US markets. In either case, the information asymmetry would be likely to impact foreign equity markets as we show below.

One question about our results is the long-lived nature of the private information shock. Our results are bracketed by results in other papers that look at the effects of private information based trading. For example, Hasbrouck (1991) examined the impact of private information on quote revisions that occur up to 20 transactions later. In contrast, Easley, Hvidkjaer and O'Hara (2002) find that a measure of a stock's probability of information-based trading is priced in the cross section of US stocks using monthly data.

Our results have implications for papers that attempt to link private information and other market frictions to domestic asset prices. For example, other papers have explored systematic factors in liquidity and their link to the cross section of US stock returns (Chordia, Roll and Subrahmanyam (2000), Hasbrouck and Seppi (2001) and Pastor and Stambaugh (2003)). We note that liquidity and private information based

policy on US stocks include Schwert (1981), Pearce and Roley (1985), Hardouvelis (1987), Jensen, Mercer and Johnson (1996), Patelis (1997), Thorbecke (1997), and Bernanke and Kuttner (2003). Changes in US monetary policy also affect foreign equity markets (Kim (2001)).

29 Melvin (2002) finds that the exchange rate market switches to a more informed state on FOMC days, suggesting greater private information revelation. 
trading are linked in many microstructure models. Our finding of a role of common private information may therefore provide some guidance for the economic origins of systematic liquidity.

\section{The Cross-Section of International Equity Returns}

The previous sections have shown that private information based trading predicts both US money and equity market returns over daily and weekly holding periods. In addition, public information shocks in the Eurodollar market associated with policy changes affect US equity prices. If international equity markets are integrated then the factors which affect US equity markets will affect international markets also. In this section, we explore whether these shocks are priced by estimating a latent factor model of the cross section of international equity returns.

\subsection{Latent factor model}

To test whether the US information shocks are priced factors in international markets, we use the latent-factor model of Hansen and Hodrick (1983) and Gibbons and Ferson (1985). In this model, the excess return on a foreign asset $i$ is a function of the realizations of $K$ factors:

$$
r_{i, t+1}=E_{t}\left[r_{i, t+1}\right]+\beta_{i} f_{t+1}+\varepsilon_{i, t+1}
$$

where $f$ is a $K \times 1$ vector of factor realizations with $E_{t}\left[f_{t+1}\right]=0, \beta_{i}=\operatorname{cov}\left(r_{i, t+1}, f_{t+1}\right)$ is a $1 \times K$ vector of constants, and $\varepsilon_{i}$ is an idiosyncratic error, uncorrelated with $f$. Equilibrium requires that the expected return on the asset be a function of the $K$ sources of risk:

$$
E_{t}\left[r_{i, t+1}\right]=\beta_{i} \theta_{t}
$$

where $\theta_{t}$ is a $K \times 1$ vector that contains the market price of risk of the factors.

In the latent factor approach, the factors are not specified directly. Rather there are a number of instruments that forecast returns in the markets and are likely related to the true, but unknown, factors. The price of risk of the $k$-th factor $\theta_{k, t}$ is written as a linear combination of the set of $N$ instruments $I_{t}$ :

$$
\theta_{k, t}=\alpha_{k} I_{t}
$$

where the $\alpha_{k}$ are coefficients.

When we combine our assumption of the process driving returns (11), the equilibrium condition (12) and the assumption on the market price of risk (13), we obtain a non-linear 
pricing equation for asset $i$

$$
r_{i, t+1}=\beta_{i} \alpha I_{t}+\widetilde{\varepsilon}_{i, t+1}
$$

where the $K \times N \alpha$ matrix contains the $\alpha_{k}$ coefficients on the instruments for the $K$ factors and $\widetilde{\varepsilon}_{i, t+1}=\beta_{i} f_{t+1}+\varepsilon_{i, t+1}$. This model is used to examine the cross-section of $M$ assets via:

$$
R_{t+1}=\beta \alpha I_{t}+\widetilde{\varepsilon}_{t+1}
$$

Here, $R_{t+1}$ is the $M$ vector containing the quote revisions on the foreign countries. The $M$ by $K$ matrix $\beta$ is the loading of the returns on the time-varying factor returns. The $K$ by $N$ matrix $\alpha$ are the coefficients on the instruments; the linear combination $\alpha I_{t}$ represents the time-varying return on the latent factors.

As the factors are latent in this model, the ability of the model to price the crosssection of international equity returns will depend on the selection of the instruments. Campbell (1996) makes the point that the factors which price the cross-section of asset returns should be the innovations to those variables that can forecast the moments of the investment opportunity set. In our model, with the assumption of international market integration, the innovations on those variables which forecast US asset returns will be able to forecast the international investment opportunity set. ${ }^{30}$ Thus, we use the public and private information variables from our time-series regressions as our instruments:

$$
\begin{aligned}
I_{t}= & \left(\text { constant }, P_{t-1}^{T R}, S P_{t-1}, v(x)_{t}^{E D}, v(r)_{t}^{E D} \cdot 1(\Delta T R=0),\right. \\
& \left.v(r)_{t}^{E D} \cdot 1(\Delta T R \neq 0), v(x)_{t}^{U S}, v(r)_{t}^{U S}\right) .
\end{aligned}
$$

Our information set $I_{t}$ includes the monetary policy variables that were shown to have some predictability for the Eurodollar and US ETF markets. We also include the unanticipated order flow and quote revision from the Eurodollar money market regressions, (7) and (9), respectively. Note that we segregate the public information shocks into those that have occurred as a function of target rate changes $(\Delta T R \neq 0)$ and those that have not $(\Delta T R=0)$. Finally, we include the unanticipated order flow and quote revision from the US equity market regressions, (8) and (10), respectively.

Our interest centers on the public and private information content of the shocks from the Eurodollar and US equity markets. The unanticipated quote revisions represent public information news in the two markets. As mentioned above, the unanticipated order flows will contain elements related both to microstructure (e.g., liquidity or inventory)

\footnotetext{
30 In previous asset pricing tests, the instruments $I_{t}$ were the "usual suspects" that have been found to forecast returns at monthly horizons. Examples include dividend yields, term structure slopes, short term interest rates and credit spreads, among others. Here we focus on variables that have predictive ability over shorter horizons.
} 
effects and to shocks to the private information sets of sophisticated investors. Over longer holding periods, the microstructure effects will disappear and the information effects of the trades may be obtained by estimating:

$$
R_{t+H}=\beta_{H} \alpha_{H} I_{t}+\widetilde{\varepsilon}_{H, t+1},
$$

where $R_{t+H}$ is the vector of $H$-period returns on the foreign equity markets. If private information is part of a priced factor, the $\alpha_{H}$ coefficients associated with the unanticipated order flows will be significant for longer holding periods (e.g. $H=1$ day or 1 week).

The model is estimated by Generalized Method of Moments. We estimate the system (14) separately for each holding period $H$. The Newey-West (1987) form of the optimal weighting matrix is used to capture any autocorrelation of heteroskedasticity in the residuals. In its present form the model is unidentified due to the $\beta_{H} \alpha_{H}$ combination. We thus impose the standard identification that the first $K$ rows of the matrix $\beta_{H}$ are equal to an identity matrix. The cross-equation restrictions of the model can be tested using the standard $\chi^{2}$ test statistic from a GMM system.

Using the latent factor model to capture the cross section of returns has a number of advantages. ${ }^{31}$ In this paper, as with other empirical studies of market frictions on asset prices (e.g. Pastor and Stambaugh (2002), Hou and Moskowitz (2003)), we do not specify a model that directly ties asymmetric information to the cross section of expected international returns. ${ }^{32}$ Our approach is more in the spirit of Campbell (1996) who shows that the cross section of returns should be explained by those factors that can predict time variation in the investment opportunity set. Given the time series results above, the factors we have chosen should have some power to explain the cross section. The advantage of the latent factor model is that it can capture the pricing ability in a parsimonious setting.

Another advantage of the latent factor model is that it allows the data to reveal the structure of the cross section of expected returns. This can answer a number of questions. For example, are private and public information shocks separate factors or part of the same factor? Do all of the countries examined load on the same shocks? Alternatively, as noted by Campbell and Hamao (1992), the latent factor model can be evaluated simply by its ability to describe the cross section of returns.

\footnotetext{
31 Latent factor models have been used in a number of domestic and international asset pricing tests. See Ferson (1995) for a survey.

32 See, however, Easley, Hvidkjaer and O'Hara (2002) for such a model on domestic stock returns. A model that relates returns and flows to private information in an international setting is provided by Albuquerque et al. (2003b). However, they do not test the effects of private information on the cross section of asset prices.
} 


\subsection{Results}

We started by estimating a standard one factor model. However, this specification was rejected for all holding periods. We therefore estimate a two latent factor model; the summary statistics are presented in Table 6 . The $\chi^{2}$ test statistics of the cross-equation restrictions on the parameters are presented at the top of the table along with their asymptotic marginal significance levels $(P$-values). The statistics show that the two factor model is rejected for the one-half-hour $(H=1)$ returns while it is not rejected for the daily and weekly returns ( $H=1$ and 5 days). To judge whether the model does a good job in capturing expected equity returns we present some variance ratios. The numerator of the ratio is the variance of the expected return on the foreign country ETF from the two latent factor model. The denominator is the variance of the expected return from a regression of the ETF return on the same instruments. If the model does a good job in capturing expected return variation then the ratio should be near 1.00. As can be seen, the ratios are near 1.00 for the half-hour and daily holding periods while they decline for some countries for the weekly interval.

The results of these tests contain a mixed message for the model. Formally, our choice of instruments and the over-identifying restrictions are rejected for the half-hour holding period. However, the variance ratios indicate that the model does a good job in capturing the time series properties of the conditional means. The conflict between the two tests is likely due to short-run microstructure effects such as inventory rebalancing or liquidity shocks. The microstructure effects will be captured (in part) by our instruments and will affect half-hour holding period returns as the market maker adjusts her quotes to the shocks. However, the quote adjustment process appears to be more complicated over half-hour intervals than that captured by the factor model. The large number of data points $(15,598)$ means that we can detect these small differences, even though the model is capturing a large portion of the predictable returns based on these instruments.

At longer holding periods of a day to a week, the microstructure effects disappear and pricing decisions are driven by the assessment of information in the market. Here the combination of our instruments and the over-identfying restrictions of the model are not rejected indicating that the information effects driving longer horizon returns are less complicated than the shorter-run microstructure effects. Thus, given the formal model tests and the variance ratio results we will use the two latent variable model as our starting point for analyzing the cross section of international returns.

Table 7 presents the estimates of the $\beta_{H}$ coefficients for the 12 foreign countries and the three holding periods. In this two factor model, the coefficients on the German and

Japanese returns are normalized to an identity matrix for identification. For the half-hour 
holding period, most of the countries load on the two factors with significant coefficients. As the holding periods increase, the influence of the second factor diminishes while that of the first factor grows. At the weekly holding period, the coefficients on the first factor are significant for equities from all countries (the Swedish coefficient is significant at a 10 per cent level). The second factor is a "pure" Japanese factor as it receives a (normalized) weight of 1.00 on Japanese returns and statistically insignificant loadings on the other countries' returns. Thus it appears that at a weekly interval, Japanese equity market returns are not integrated with the returns in other markets.

An examination of the $\alpha_{H}$ coefficients reveals which of the individual factors are priced in the cross section. Table 8 presents these estimates for the two factors over the three holding periods. Each cell contains three numbers; the first two are the estimated coefficient from the model and its $t$ statistic. The third number $[\sigma$-shock $]$ is designed to show the economic significance of the indicated variable. It is calculated as the absolute value of the estimated $\alpha_{H}$ coefficient times a one standard deviation shock to the variable divided by the standard deviation of the latent factor. It is thus similar to a (normalized) one standard deviation shock impulse response function.

One immediate impression from the table is that the two factors are quite similar. While the coefficients are statistically different in many cases (which yields the two factor model) their signs and magnitudes are roughly similar. Thus the linear combination of the first factor is similar to the linear combination of the second factor. With so many data points there is sufficient power to capture small differences in the factors. Recall that the second factor is a pure Japanese factor for the longest holding period suggesting that Japanese equity markets are segmented from those in the rest of the world. The results of this table suggest that while the segmentation is present it is not so severe as to completely change the relationship between the instruments and expected return in this market.

A detailed examination of the coefficients can start with the monetary policy variables in the first two columns. As with the US equity return regressions, these instruments show little ability to price the cross section of international returns. The sole exception is at the weekly horizon where the instruments are statistically significant in the second factor. In addition, they are large economically as a one standard deviation shock to the lagged price of the Fed funds target (the Eurodollar spread) equals 58.2 per cent (80.7 per cent) of the variability of the factor. As this is the factor that loads on Japanese equity returns it suggests that the most important thing for weekly Japanese equity returns is the anticipated state of US monetary policy.

The next three columns measure the spillover effects from the Eurodollar market to the foreign equity markets. At the longer holding periods, the unanticipated Eurodollar 
purchases $\left(v(x)_{t}^{E D}\right)$ represent the effects of private information released during US trading times. The coefficients on this variable are significant and negative again in line with the US ETF results. Thus, private information released in the US money market is part of the priced factor in the international cross section. The effects of the private information shocks are also economically important as a one standard deviation shock to the variable accounts for approximately 20 per cent of the volatility of the two factors at a weekly horizon.

Unanticipated Eurodollar quote revisions $\left(v(r)_{t}^{E D}\right)$ represent public news shocks. Shocks that are not associated with monetary policy moves $(\Delta T R=0)$ are not statistically significant at any horizon. Shocks that are associated with monetary policy innovations $(\Delta T R \neq 0)$ have a negative coefficient and are significant. Changes in US interest rates are priced in the international markets when they are associated with policy changes. This may indicate that previous tests which looked at the effects of US interest rates on international markets may be misspecified. If only policy innovations are priced, the it is important to distinguish between the two types of shocks.

The policy-driven public information shocks have a large impact on short horizon returns. For example, at a half-hour interval the shock accounts for 78.9 per cent (52.1 per cent) of the first (second) factor's variability. As the forecast horizon lengthens, the economic significance of the public information shock declines. At a one week horizon, the shock accounts for less than 20 per cent. This suggests that the public information becomes quickly incorporated into prices while it takes longer for agents to infer the private information element of the trades.

The final two columns show the coefficients associated with private and public information shocks arising in the US equity market. These shocks are also priced in the cross section of international equities. Public information shocks in the US equity market $\left(v(r)_{t}^{U S}\right)$ are a priced factor in foreign equity returns, in line with previous low-frequency studies that use excess US equity market returns (e.g. Campbell and Hamao (1992), Bekaert and Hodrick (1992)). The new result here is that private information shocks are also a priced factor. The coefficients on unanticipated net purchases are significant even out to a weekly horizon. Sophisticated US investors obtain information that is related to the common factors which influence asset prices around the world. When they trade in the US equity index market, market makers in the ETFs can use this information to set foreign equity prices.

Private information shocks are also economically important as the effect on the first factor is equal to 17.4 per cent of the volatility of the factor at a weekly horizon. We note that this is similar in magnitude to the private information shocks originating in the Eurodollar interest rate market. The $\sigma$-shock measures are large for the public 
information shocks even out to a weekly horizon suggesting that public information shocks take a long time to be absorbed by the market. However, this may be misleading as there will be factors other than the money market shocks which will be analyzed by sophisticated investors.

\subsection{Interpretation}

In the international literature, private information is used as an explanation of the home bias phenomenon (French and Poterba (1991), Gehrig (1993), Brennan and Cao (1997) and Coval (1999)). In these models, sophisticated agents have superior information about returns on stocks in their own countries; i.e. German investors have superior knowledge about German firms which US investors could not obtain. This generates an additional source of risk to investing in international stocks which leads agents to invest in domestic equities.

This simple view of the structure of private information has been challenged by Albuquerque et al. (2003a) who show that sophisticated US investors have private information about global factors that affect returns in many countries. They rely on a factor analysis of monthly international transactions by US residents to generate the global factor. We improve on their findings in two ways. First, we use high-frequency data to identify public and private information shocks based on well established approaches from the microstructure literature. Second, we show that international private information based trading is related (in part) to a specific economic fundamental, monetary policy. As with our domestic market analysis above, we acknowledge that there may be other important economic sources of private information that we are not modeling.

The origins of the private information can be motivated in two ways. Sophisticated agents such as hedge funds can conduct "top-down" analyses where they generate private information about macroeconomic fundamentals from a superior interpretation of public information. The fundamentals could be related to either the US or foreign economies. In either case, with integrated international markets, such information would be useful for capturing return variation in many countries. The large numbers of Ph.D.s employed by such funds to generate private trading opportunities is consistent with this story. We note that, as with our domestic results, this private information about monetary policy does not come from information leakages from the Fed.

Alternatively, order flow in the US markets could be acting as a "bottom-up" aggregator of diffuse private information. Evans and Lyons (2004) present a model of the foreign exchange market where order flow aggregates the dispersed private information about productivity shocks in the two countries. They note that while productivity shocks 
would occur at the level of the firm, aggregate trades by agents in the country would give a more precise estimate of the country's productivity shock that period. They also note that agents' trades could be aggregating information about other variables that are realized at the micro level such as money demand. Our US shocks can be interpreted as money demand shocks and real shocks arising from firm level information. Financial firms in the US that observe a large cross section of customer order flow could then extract such information and use it for proprietary trading. Again, with integrated markets, such US information shocks would have an international effect.

One question that we cannot answer from our data set is the identity of the agents generating the private information. We are only able to identify all private information generated during US trading hours in US markets. The information could come from sophisticated investors from many countries who are trading in US markets. For example, foreign sophisticated investors (e.g. hedge funds) could have superior information about US based factors if they devote significant resources to obtaining the information and are able to profit from trading on it. In this sense, what matters more for international markets is the degree of investor sophistication, not the country in which they reside (Albuquerque et al. (2003b)).

\subsection{Country-specific information}

Our analysis so far has concentrated on the effects of global factors in the cross section of international equity returns. We have interpreted these factors as originating in sophisticated investors knowledge of aggregate US market factors. However, sophisticated investors may also do individual country analyses. This suggests that a potentially important source of private information remains unexplored.

To obtain the country-specific private information of sophisticated investors, we use a similar time series regression to model the order flows of the individual ETFs. Following our time series approach above, we can model the order flow from foreign country $j$ as:

$$
\begin{aligned}
x_{t}^{j}= & a(L) r_{t}^{E D}+b(L) x_{t}^{E D}+c(L) r_{t}^{U S}+d(L) x_{t}^{U S}+e(L) r_{t}^{j}+f(L) x_{t}^{j} \\
& +g P_{t-1}^{T R}+h S P_{t-1}+m v(x)_{t}^{E D}+n v(x)_{t}^{U S}+v(x)^{j} .
\end{aligned}
$$

Here the foreign order flow that occurs during US trading times is a function of past quote revisions and order flows in the US money and equity markets as well as the foreign ETF market. Including these variables (lagged public information) captures the standard microstructure effects mentioned above. Also included are the monetary policy variables (the lagged price of the Federal funds target and the target spread). The effect of contemporaneous shocks to private information in the US money and equity markets 
will be captured by the residual from the money market equation (7) and the residual from the US equity market regression (8), respectively.

Table 9 presents the results of the foreign order flow regressions. The instruments can capture some of the predictability of the order flows with adjusted $R^{2}$ statistics ranging from 0.011 for the Netherlands to 0.178 for Japan. Again these are in line with other estimates of equity market order flows. The coefficients on the lagged microstructure variables are not in general significant and are not reported. However, there are some interesting results on the other variables. The coefficients on the monetary policy variables match their counterparts in the US ETF regression shown in Table 5 (a negative coefficient on the lagged price of the target and a positive coefficient on the lagged Eurodollar - target spread). Given that it is the opposite of the coefficients in the Cochrane-Piazzesi regressions in Table 3, this indicates that US agents tend to sell foreign equities when the Eurodollar interest rate is expected to rise.

We note that private information based trading from the US money and equity markets also has an effect on trades in the foreign ETFs. Unanticipated US equity market trades are significant for 11 of the 12 foreign countries (Sweden is the exception). As agents receive private information about aggregate factors in the economy, they tend to buy both US and foreign stocks to obtain exposure to these factors. The effect of the unanticipated money market trades is not as strong with seven of the 12 coefficients being significantly negative. Nevertheless, all but one of the coefficients are negative indicating a common purchasing pattern.

The residuals from (15) represent private information and liquidity shocks to US agents that are orthogonal to those shocks arising from aggregate money and equity market factors. We can incorporate these "country specific" effects into our latent variable model of the cross section via

$$
R_{t+H}=\beta_{H} \alpha_{H} I_{t}+\Lambda_{H} * V(x)^{j}+\varepsilon_{H, t+1}
$$

where $V(x)^{j}$ is an $M \times 1$ vector containing the residuals from (15) and $\Lambda$ is a $M \times 1$ vector of coefficients and $*$ represents element-by-element multiplication. We can estimate the system (16) by Generalized Method Moments following the same procedure outlined above.

Table 10 shows the elements of the $\Lambda$ vector along with their $t$ statistics for the three holding periods (1/2 hour, 1 day and 5 days). ${ }^{33}$ The $\chi^{2}$ test statistics at the bottom of the table indicate that the vector of coefficients is jointly significant for all of the holding periods indicating that country-specific private information is revealed during US trading

\footnotetext{
33 For computational efficiency, we fix the $\alpha$ and $\beta$ coefficients to their values presented above. If we allow them to be estimated, the values are very similar to those reported above in tables 8 and 9 .
} 
times. What is quite interesting is the pattern of the coefficients. The coefficients are statistically significant and positive for all of the countries at the half-hour interval. Over a five day holding period, only 5 of the 12 foreign countries have a significant and positive coefficient. Two of the countries (UK and Netherlands) have significantly negative coefficients. The remaining five coefficients are insignificant.

One possible interpretation of this pattern can be had by viewing the trades in the US as arising predominately from trades by US investors. Under this scenario, sophisticated US investors would have superior information about US macroeconomic factors that affect returns on equities in many countries (Albuquerque et al. (2003a)). When they trade on this information, the information is gradually incorporated into prices as shown in the previous section. However, US agents may have much less precise information about country-specific factors compared to foreign investors. For example, it is hard to see how US agents could have superior information about factors that affect German stock returns that are orthogonal to the global factors in their information set. Thus when US investors trade on these country-specific factors they may lose to better informed foreign investors. The relatively poor performance of their trades in many of these countries gives some support to this view.

\subsection{Home-currency returns}

A number of papers have shown that asymmetric information is a significant driver of exchange rates (Lyons (1995, 2001), Evans and Lyons (2002), Covrig and Melvin (2002)). If sophisticated investors generate private information about foreign exchange rates, they will be able to trade assets denominated in the foreign currencies and make a profit. This may be driving our results as the price of the foreign ETF that is traded in US markets tracks the home currency price of the index and is translated into US dollars. Thus the US dollar return on the foreign ETF is composed of a home currency return on the index and a change in the value of the foreign exchange rate. It follows that the results of our previous analysis could be due to sophisticated investors generating private information about the foreign exchange component rather than the foreign equity component.

To show that the results for the equity markets were not solely due to exchange rate effects we construct home-currency equity returns by dividing the US dollar price of the foreign country ETF by the foreign exchange rate from the futures market:

$$
r_{t, t+H}^{H C} \equiv \log \left(P_{t+H}^{E T F} / P_{t+H}^{F C}\right)-\log \left(P_{t}^{E D} / P_{t}^{F C}\right) .
$$

where $P_{t}^{F C}$ is the price of the foreign currency futures contract at time $t$. We note that this return is only approximate as the spot exchange rate price should have been used; 
however, these are unavailable to us in microstructure time. Also, the variability of the futures price will be dominated by movements in the spot exchange rate. We can project these home-currency equity returns on the latent factors from our model :

$$
r_{t, t+H}^{H C}=\varphi_{H}\left(\widehat{\alpha}_{H} I_{t}\right)+\varepsilon_{H, t+1}^{*},
$$

where $\widehat{\alpha}_{H}$ are the estimated coefficients from the GMM estimation of (14). If the exchange rate effects do not matter then the coefficients in this regression should be close to the $\beta_{H}$ coefficients from the original GMM estimation. The null hypothesis is then

$$
H_{0}: \widehat{\varphi}_{H}=\widehat{\beta}_{H}
$$

Table 11 presents the OLS estimates of (17) and the asymptotic $t$ test statistics associated with (18). The parameter estimates of the loadings of the home currency returns are similar to the loadings on the US dollar returns in Table 9. For example, the loadings on Germany and Japan for the two factors are normalized to an identity matrix in the original (over-identified) model. Here, the OLS coefficients for the same two countries somewhat resemble an identity matrix. The coefficients on the UK and Swiss returns are significant for the first factor for a holding period of one week.

The $p$-values of the test statistics associated with (18) are at the bottom of the table. At a 5 per cent significance level, all but three of the individual coefficients are statistically the same as their unadjusted counterparts in Table 7. However, there is enough power to reject the joint equivalence of both statistics in many of the short horizon returns and in some of the longer horizon returns. These mixed results suggest that the change in the foreign exchange rates are somewhat related to the linear combination of the selected instruments obtained from the equity pricing model. However, the earlier results were not solely driven by this phenomenon.

\section{Conclusions}

The goal of this paper is to deepen our understanding of the links between foreign asset movements and news (public and private) arising in US money and equity markets. Recent studies using high frequency data have shown that public news about US money and equity markets affect equity markets abroad (Andersen et al. (2003)). Our main contribution is to show that some agents have superior knowledge about future US interest rates and aggregate equity market returns. This superior knowledge is partially revealed through trades which affect equity markets abroad. This finding gets to the core of

Goodhart and O'Hara's (1997) question as to how private information can have a global 
impact. Not only do we show that public and private information about US interest rates and aggregate equity markets predict future foreign equity market movements, but we also show that these are components of factors that are priced in the international cross section.

These findings suggest further research in the behavior of domestic and foreign markets. In recent work, Pastor and Stambaugh (2003) and others show that market wide liquidity is a state variable important for domestic asset pricing. Liquidity is defined as temporary price fluctuations induced by order flow. In contrast, private information is defined as permanent price fluctuations induced by order flow. The literature has largely treated these as distinct concepts. However, as noted by Kyle (1984), the two quantities are correlated as informed traders prefer to strategically place trades in liquid markets to hide their behavior and maximize their profits. Future research on asset returns should attempt to distinguish between the two effects and determine their economic origins. 


\section{References}

[1] Albuquerque, Rui, Gregory H. Bauer, and Martin Schneider (2003a), "Characterizing Asymmetric Information in International Equity Markets," mimeo, University of Rochester.

[2] Albuquerque, Rui, Gregory H. Bauer and Martin Schneider (2003b), "International Equity Flows and Returns: A Quantitative Equilibrium Approach," mimeo, University of Rochester.

[3] Andersen, T., T. Bollerslev, F.X. Diebold and C. Vega (2003) "Micro Effects of Macro Announcements: Real-Time Price Discovery in Foreign Exchange, " American Economic Review, 93, 38-62.

[4] Bekaert, Geert and Robert J. Hodrick, 1992, "Characterizing Predictable Components in Excess Returns on Equity and Foreign Exchange Markets" Journal of Finance, 47(2) 467-509.

[5] Bernanke, Ben and Kenneth N. Kuttner (2003), "What Explains the Stock Market's Reaction to Federal Reserve Policy," working paper.

[6] Brennan, Michael J., and H. Henry Cao (1997), "International Portfolio Investment Flows," The Journal of Finance, 52, 1851-1880.

[7] Brennan, Michael J. and Subrahmanyam A. (1996), "Market Microstructure and Asset Pricing: On the Compensation for Illiquidity in Stock Returns," Journal of Financial Economics, 41, 441-464.

[8] Brennan, Michael J., Narasimhan Jegadeesh and Bhaskaran Swaminathan (1993), "Investment Analysis and the Adjustment of Stock Prices to Common Information," The Review of Financial Studies, 6, 799-824.

[9] Campbell, John Y. (1996), "Understanding Risk and Return," Journal of Political Economy, 104, 298-345.

[10] Campbell, John Y. and Yasushi Hamao (1992), "Predictable Stock Returns in the United States and Japan: A Study of Long-Term Capital Market Integration", The Journal of Finance, 47, 43-69.

[11] Carlson, John B., Jean M. McIntire and James B. Thomson (1995), "Federal Funds Futures as an Indicator of Future Monetary Policy: A Primer," Economic Review, 20-30. 
[12] Chan, Kalok (1993), "Imperfect Information and Cross-Autocorrelation among Stock Prices," Journal of Finance 48:1211-1230.

[13] Chordia, Tarun, Richard Roll and Avavidhar Subrahmanyam (2000), "Commonality in Liquidity," Journal of Financial Economics, 56, 3-28.

[14] Cochrane, John H. and Monika Piazzesi (2002), "The Fed and Interest Rates: A High-Frequency Identification," American Economic Review Papers and Proceedings, 92, 90-95.

[15] Connolly, R. and A. F. Wang (2002), "International Equity Market Comovements: Economic Fundamentals or Contagion?" Pacific-Basin Finance Journal, forthcoming.

[16] Coval, Joshua (1999), "International Capital Flows when Investors have Local Information," University of Michigan, mimeo.

[17] Covrig, Vincentiu and Michael Melvin (2002), "Asymmetric Information and Price Discovery in the FX Market: Does Tokyo Know More About the Yen?," Journal of Empirical Finance, .

[18] Craig, Alastair, Ajay Dravid and Matthew Richardson (1995), "Market Efficiency Around the Clock Some Supporting Evidence in Using Foreign-Based Derivatives," Journal of Financial Economics, 39, 161-180.

[19] Easley, David, and Maureen O'Hara (1987), "Prices, trade size and information in security markets," Journal of Financial Economics, 19, 69-90.

[20] Easley, David, and Maureen O'Hara (2002), "Microstructure and Asset Pricing," in G.M. Constantinides, M. Harris and R. Stulz (eds.), Handbook of Economics of Finance. Elsevier-North Holland, forthcoming.

[21] Easley, David, Soeren Hvidkjaer and Maureen O'Hara (2002), "Is Information Risk a Determinant of Asset Returns?", The Journal of Finance, 57, 2185-2221.

[22] Ellis, Katrina, Roni Michaely and Maureen O'Hara (2000), "The Accuracy of Trade Classification Rules: Evidence from Nasdaq," Journal of Financial and Quantitative Analysis, 35, 529-551.

[23] Elton, E. J., J. M. Gruber, G. Comer and K. Li (2002) "Spiders: Where Are the Bugs?," Journal of Business, forthcoming. 
[24] Engle, Robert F., Ito Takatoshi and Wen-Ling Lin (1990), "Meteor Showers or Heat waves? Heteroskedastci Intra-Day Volatility in the Foreign Exchange Market," Econometrica, 58, 525-542.

[25] Evans, Martin D.D. and Richard K. Lyons (2002), "Order Flow and Exchange Rates", Journal of Political Economy, 110, 170-180.

[26] Evans, Martin D.D. and Richard K. Lyons (2004), "A New Micro Model of Exchange Rate Dynamics", mimeo, University of California Berkeley.

[27] Fair, C. Ray, (2003) "Shock Effects on Stocks, Bonds, and Exchange Rates," Journal of International Money and Finance, 22, 307-341.

[28] Ferson, Wayne E. (1995), "Theory and Empirical Testing of Asset Pricing Models," in R.Jarrow et al. (eds.), Handbooks in OR \& $M S$, vol. 9, 145-200.

[29] French, Kenneth, and James Poterba (1991), "Investor Diversification and International Equity Markets," American Economic Review Papers and Proceedings, 81,222226.

[30] Gehrig, Thomas (1993), "An Information Based Explanation of the Domestic Bias in International Equity Investment," Scandinavian Journal of Economics, 95, 97-109.

[31] Gibbons, Michael R. and Wayne Ferson (1985), "Testing Asset Pricing Models with Changing Expectations and an Unobservable Market Portfolio", Journal of Financial Economics, 14, 217-236.

[32] Glosten, Lawrence R., and Paul R. Milgrom (1985), "Bid, Ask and Transaction Prices in a Specialist Market with Heterogeneously Informed Traders," Journal of Financial Economics, 14, 71-100.

[33] Goodhart, A.E. Charles and Maureen O'Hara (1997), "High Frequency Data in Financial Markets: Issues and Applications," Journal of Empirical Finance, 4, 73114.

[34] Hamao, Y., R.W. Masulis and V.K. Ng (1990), "Correlations in Price Changes and Volatility across International Stock Markets," Review of Financial Studies, 3, 281307.

[35] Hansen, Lars P. and Robert J. Hodrick (1983), "Risk Averse Speculation in the Forward Foreign Exchange Market: An Econometric Analysis of Linear Models", in 
Jacob A. Frenkel (ed.), Exchange Rates and International Macroeconomics. Chicago: The University of Chicago Press.

[36] Hardouvelis, Gikas A. (1987), "Macroeconomic Information and Stock Prices," Journal of Economics and Business, 39, 131-140.

[37] Hasbrouck, Joel (1991), "Measuring The Information Content of Stock Trades," The Journal of Finance, 46, 179-207.

[38] Hasbrouck, Joel (1996), "Modeling Market Microstructure Time Series," Handbook of Statistics, 14, 647-692.

[39] Hasbrouck, Joel and Duane J. Seppi (2001), "Common Factors in Prices, Order Flows and Liquidity," Journal of Financial Economics, 59, 383-411.

[40] Hou, Kewei and Tobias J. Moskowitz (2003), "Market Frictions, Price Delay and the Cross-Section of Expected Returns," working paper.

[41] Jensen, G. R., J.M. Mercer and R.R. Johnson (1996), "Business Conditions, Monetary Policy, and Expected Security Returns," Journal of Financial Economics, 40, 213-237.

[42] Karolyi, G. Andrew, and Rene M. Stulz (1996), "Why Do Markets Move Together? An Investigation of U.S.-Japan Stock Return Comovements," The Journal of Finance, 51, 951-985.

[43] Kim, Soyoung (2001), "International Transmission of US Monetary Policy Shocks: Evidence from VAR's," Journal of Monetary Economics, 48, 339-372.

[44] King, Mervyn and Sushil Wadhwani (1990), "Transmission of Volatility Between Stock Markets", The Review of Financial Studies, 3, 5-33.

[45] King, Mervyn, Enrique Sentana and Sushil Wadhwani (1994), "Volatility and the Link Between National Stock Markets", Econometrica, 62, 901-33.

[46] Kuttner, Kenneth N. (2001), "Monetary Policy Surprises and Interest Rates: Evidence from the Fed Funds Futures Market," Journal of Monetary Economics, 47, 523-544.

[47] Kyle, Albert S., (1985) "Continuous Auctions and Insider Trading," Econometrica, $53,1315-1335$. 
[48] Lee, Charles M. and Mark Ready (1991), "Inferring Trade Direction from Intraday Data," The Journal of Finance, 46, 733-746.

[49] Lin, W., Engle, R., and T. Ito (1994), "Do Bulls and Bears Move accross Borders? International Transmission of Stock Returns and Volatility," Review of Financial Studies, 7, 507-538.

[50] Lyons, Richard K. (1995), "Tests of Microstructural Hypothese in the Foreign Exchange Market", Journal of Financial Economics, 321-351.

[51] Lyons, Richard K. (2001), The Microstructure Approach to Exchange Rates, MIT Press.

[52] Madhavan, A., M. Richardson and M. Roomans, (1997), "Why Do Security Prices Change? A Transaction-Level Analysis of NYSE Stocks," Review of Financial Studies 10(4), 1035-1064.

[53] Melvin, Michael (2002), "Exchange Rates and FOMC Days", mimeo, Arizona State University.

[54] Newey, W. and K. West (1987), "A Simple Positive-Definite Heteroskedasticity and Autocorrelation Consistent Covariance Matrix," Econometrica 55, 703-708.

[55] O'Hara, Maureen (1997), Market Microstructure Theory, Blackwell Publishers.

[56] Pastor, Lubos and Robert F. Stambaugh (2003), "Liquidity Risk and Expected Stock Returns", Journal of Political Economy, 111, 642-685.

[57] Patelis, A. (1997), "Stock Return Predictability and the Role of Monetary Policy," The Journal of Finance, 52, 1951-1972.

[58] Pearce, Douglas K. and V. Vance Roley (1985), "Stock Prices and Economic News," Journal of Business, 58, 49-67.

[59] Rudebusch, Glenn D. (1998), "Do Measures of Monetary Policy in a VAR Make Sense", International Economic Review 39(4), 907-31.

[60] Saar, Gideon (2001), "Investor Uncertainty and Order Flow Information", working paper, New York University.

[61] Saar, Gideon and Lei Yu (2002), "Information Asymmetry about the Firm and the Permanent Price Impact of Trades: Is there a Connection?", working paper, New York University. 
[62] Schwert G. William (1981), "The Adjustment of Stock Prices to Information about Inflation," The Journal of Finance, 36, 15-29.

[63] Subrahmanyam, Avanidhar (1991), "A Theory of Trading in Stock Index Futures," Review of Financial Studies 4:17-51.

[64] Susmel, R. and R. F. Engle (1994), "Hourly Volatility Spillovers Between International Equity Markets," Journal of International Money and Finance, 13, 3-25.

[65] Thorbecke, W. (1997), "On Stock Market Returns and Monetary Policy," The Journal of Finance, 52, 635-654.

[66] Werner, Ingrid M. and Allan W. Kleidon (1996), "U.K. and U.S. Trading of British Cross-Listed Stocks: An Intraday Analysis of Market Integration", The Review of Financial Studies, 9, 619-664.

[67] Yu, Lei (2003), "Basket Securities, Price Formation and Informational Efficiency", working paper, New York University. 


\section{Figure 1}

\section{Six-month Eurodollar Futures and Fed Funds Target Rate}

The two solid lines are the daily 6-month Eurodollar futures rate and the actual target-rate. The sample period is from April 1, 1996 to November 30, 2001. There were 20 target-rate changes in this period. The Eurodollar futures data are from the Chicago Mercantile Exchange (CME). The target rate is from the Federal Reserve Bank of New York.

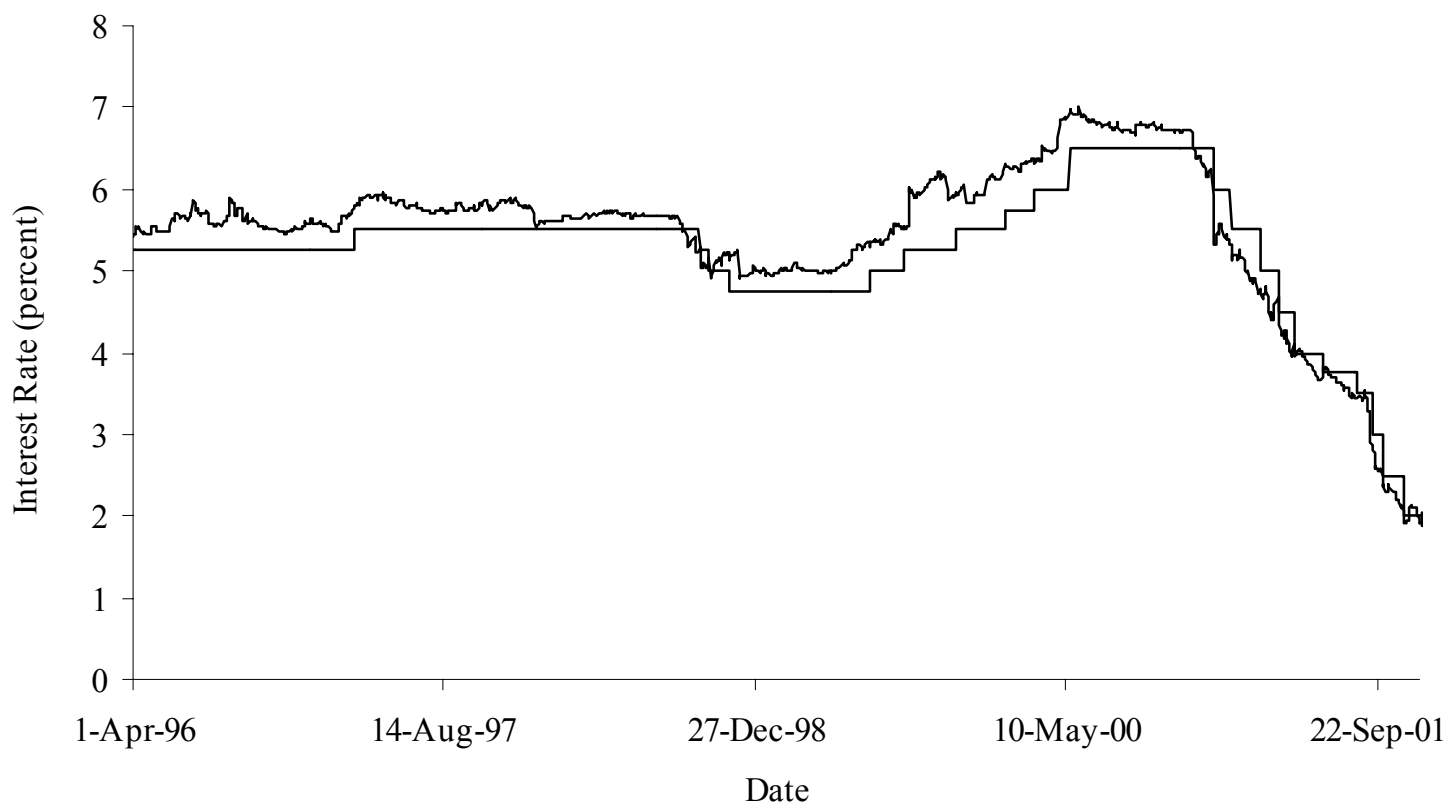


Figure 2

Timing of Quotes, Private Information, Trade Orders and Public Information

Private information is the persistent impact unanticipated trade orders have on the security price. To measure private information we estimate a system of equations similar to Hasbrouck (1991). The two main identification assumptions are the following: trade orders are in no part driven by public information and trade orders are driven partially by private information and liquidity needs. These two assumptions can be summarized as a timing convention. The timing is shown bellow, where $q_{t-1}^{b}$ is the bid quote, $q^{a}{ }_{t-1}$ is the ask quote at time $t-1$ and $x^{s}{ }_{t}$ are the seller-initiated orders and $x^{b}{ }_{t}$ are the buyer-initiated orders.

\begin{tabular}{|c|c|c|c|c|}
\hline Initial & Private & Trade Orders & Public & New Quotes \\
\hline Quotes & Information & & Information & \\
\hline$q_{t-1}^{b}, q_{t-1}^{a}$ & shock & $x_{t}^{s}, x_{t}^{b}$ & Shock & $q^{b}{ }_{t}, q^{a}{ }_{t}$ \\
\hline
\end{tabular}


Table 1a

Summary Statistics of Quote Revisions on Eurodollar Futures Contracts, Exchange Traded Funds and Foreign Currency Futures Contracts

The table shows summary statistics of quote revisions on Eurodollar futures contracts, Exchange Traded Funds (ETFs), and foreign currency futures contracts. The Eurodollar futures contracts are from the Chicago Mercantile Exchange (CME) and have a maturity of $k$ months. The US ETF is the Standard and Poor's 500 Depository Receipt ("Spider") managed by State Street Global Advisors. The foreign country exchange traded funds are the "ishares" ETFs managed by Barclay's Global Advisors. The source of the ETF data is the TAQ database. The foreign currency futures data are also from the CME and are denominated in US dollars per unit of foreign exchange. All of the series are aggregated to 11 one-half hour intervals during the common trading times of the CME and the NYSE/AMEX exchanges. The sample period is April 1, 1996 to November 30, 2001 resulting in a total of 15,598 half-hour observations. The quote revisions are the $(\log )$ change in the last quote recorded during each one-half hour interval, multiplied by 100 . The table shows the: mean; standard deviation; first and $99^{\text {th }}$ fractiles; the per cent of all intervals which have an observation ("freq"); and asymptotic marginal significance levels ( $P$-values) of the Ljung-Box test statistics for autocorrelation out to the indicated lags. The intra-day seasonality has been removed from all of the quote revisions; the final column shows the $P$-value of a test of the null hypothesis of no intra-day seasonality on the raw data.

\begin{tabular}{ccccccccc} 
& std. & \multicolumn{2}{c}{ fractiles } & & \multicolumn{2}{c}{ L.-B. Q-test } & Intra-day \\
mean & dev. & $1^{\text {st }}$ & $99^{\text {th }}$ & freq. & 1 lag & 11 lags & seasonal \\
$(\%)$ & $(\%)$ & $(\%)$ & $(\%)$ & & $(\%)$ & $(P-$ value $)$ & $(P-$ value $)$ & $(P-$ value $)$ \\
\hline
\end{tabular}

Eurodollar futures

\begin{tabular}{lcccccccc}
\hline$k=3$ & 0.0002 & 0.010 & -0.021 & 0.021 & 91.197 & $<0.001$ & $<0.001$ & 0.007 \\
$k=6$ & 0.0003 & 0.013 & -0.031 & 0.031 & 94.961 & $<0.001$ & $<0.001$ & 0.001 \\
$k=9$ & 0.0002 & 0.014 & -0.037 & 0.036 & 95.313 & 0.059 & $<0.001$ & 0.063 \\
$k=12$ & 0.0001 & 0.015 & -0.038 & 0.038 & 94.031 & 0.617 & 0.001 & 0.070 \\
$k=60$ & -0.0003 & 0.016 & -0.053 & 0.044 & 42.797 & 0.028 & $<0.001$ & 0.018
\end{tabular}

Exchange Traded Funds

\begin{tabular}{lcccccccc} 
US & -0.002 & 0.275 & -0.714 & 0.702 & 99.711 & 0.207 & 0.359 & 0.245 \\
Germany & -0.002 & 0.251 & -0.735 & 0.710 & 71.777 & 0.796 & 0.089 & 0.286 \\
Japan & -0.009 & 0.273 & -0.777 & 0.712 & 93.210 & $<0.001$ & $<0.001$ & $<0.001$ \\
UK & 0.002 & 0.245 & -0.747 & 0.714 & 61.384 & 0.028 & $<0.001$ & 0.060 \\
Switzerland & -0.002 & 0.226 & -0.776 & 0.714 & 49.580 & 0.004 & 0.027 & 0.054 \\
Canada & -0.004 & 0.273 & -0.977 & 0.856 & 41.444 & 0.234 & 0.049 & 0.214 \\
France & -0.002 & 0.217 & -0.672 & 0.643 & 57.947 & 0.889 & 0.030 & 0.017 \\
Netherlands & 0.001 & 0.213 & -0.598 & 0.632 & 46.624 & 0.048 & 0.301 & 0.052 \\
Hong Kong & -0.004 & 0.392 & -1.188 & 1.146 & 79.735 & $<0.001$ & $<0.001$ & 0.610 \\
Spain & 0.002 & 0.243 & -0.728 & 0.703 & 52.722 & 0.061 & 0.173 & 0.025 \\
Sweden & 0.001 & 0.277 & -0.825 & 0.823 & 46.759 & 0.012 & 0.016 & 0.003 \\
Australia & -0.004 & 0.241 & -0.727 & 0.654 & 46.458 & $<0.001$ & $<0.001$ & 0.090 \\
Italy & -0.004 & 0.236 & -0.714 & 0.687 & 54.754 & 0.538 & 0.036 & 0.011 \\
& & & & & & & & \\
Foreign Currency Futures & & & & & & & & \\
Euro & 0.001 & 0.120 & -0.321 & 0.314 & 93.384 & 0.244 & 0.124 & 0.003 \\
Yen & -0.002 & 0.122 & -0.326 & 0.340 & 98.442 & $<0.001$ & $<0.001$ & 0.047 \\
UK Pound & 0.002 & 0.093 & -0.249 & 0.259 & 98.211 & $<0.001$ & $<0.001$ & 0.001 \\
Swiss Franc & -0.0001 & 0.137 & -0.351 & 0.362 & 98.352 & 0.001 & 0.047 & $<0.001$ \\
Canadian \$ & -0.002 & 0.071 & -0.198 & 0.201 & 98.282 & $<0.001$ & $<0.001$ & $<0.001$ \\
& & & & & & & & \\
\hline
\end{tabular}


Table 1b

Summary Statistics of Signed Order Flows of Eurodollar Futures Contracts, Exchange Traded Funds and Foreign Currency Futures Contracts

The table shows summary statistics of signed order flows of Eurodollar futures contracts, Exchange Traded Funds (ETFs), and foreign currency futures contracts. The sources of the data are given in Table 1a. Using all observations, the signs of the trades in the Eurodollar and foreign currency futures contracts have been estimated using the "tick rule" as detailed in the text. The ETF trades from the TAQ database have been labeled as purchases or sales according to the Lee and Ready (1991) algorithm. All of the order flow series are aggregated to 11 one-half hour intervals during the common trading times of the CME and the NYSE/AMEX exchanges. The sample period is April 1, 1996 to November 30, 2001 resulting in a total of 15,598 half-hour observations. The table shows the: mean; standard deviation; the $1^{\text {st }}$ and $99^{\text {th }}$ fractiles; the per cent of all intervals which have an observation ("freq"); and asymptotic marginal significance levels ( $P$-values) of the Ljung-Box test statistics for autocorrelation out to the indicated lags. The intra-day seasonality has been removed from all of the order flows; the final column shows the $P$-value of a test of the null hypothesis of no intra-day seasonality on the raw data.

\begin{tabular}{|c|c|c|c|c|c|c|c|}
\hline \multirow[b]{2}{*}{$\begin{array}{c}\text { mean } \\
(\#)\end{array}$} & \multirow{2}{*}{$\begin{array}{c}\text { std. } \\
\text { dev. } \\
(\#)\end{array}$} & \multicolumn{2}{|c|}{ fractiles } & \multirow[b]{2}{*}{$\begin{array}{l}\text { freq. } \\
(\%)\end{array}$} & \multicolumn{2}{|c|}{ L.-B. Q-test } & Intra-day \\
\hline & & $\begin{array}{l}1^{\mathrm{st}} \\
(\#)\end{array}$ & $\begin{array}{l}99^{\text {th }} \\
(\#)\end{array}$ & & $\begin{array}{c}1 \text { lag } \\
(P-\text { value })\end{array}$ & $\begin{array}{c}11 \text { lags } \\
(P-\text { value })\end{array}$ & $\begin{array}{c}\text { seasonal } \\
(P-\text { value })\end{array}$ \\
\hline
\end{tabular}

Eurodollar futures

\begin{tabular}{|c|c|c|c|c|c|c|c|c|}
\hline$k=3$ & 0.029 & 1.521 & -4.052 & 4.041 & 91.197 & $<0.001$ & $<0.001$ & 0.003 \\
\hline$k=6$ & 0.028 & 1.990 & -5.907 & 5.093 & 94.961 & $<0.001$ & $<0.001$ & 0.001 \\
\hline$k=9$ & 0.029 & 2.257 & -6.109 & 6.000 & 95.313 & 0.013 & $<0.001$ & 0.015 \\
\hline$k=12$ & 0.011 & 2.359 & -6.915 & 6.085 & 94.031 & 0.164 & $<0.001$ & 0.195 \\
\hline$k=60$ & -0.013 & 0.802 & -2.024 & 2.020 & 42.797 & 0.131 & $<0.001$ & 0.049 \\
\hline \multicolumn{9}{|c|}{ Exchange Traded Funds } \\
\hline US & 0.886 & 14.471 & -41.506 & 40.329 & 99.679 & $<0.001$ & $<0.001$ & $<0.001$ \\
\hline Germany & 0.126 & 1.519 & -3.959 & 4.080 & 56.101 & $<0.001$ & $<0.001$ & $<0.001$ \\
\hline Japan & 0.298 & 3.022 & -7.156 & 9.183 & 88.145 & $<0.001$ & $<0.001$ & $<0.001$ \\
\hline UK & 0.067 & 1.103 & -3.021 & 2.998 & 43.848 & $<0.001$ & $<0.001$ & $<0.001$ \\
\hline Switzerland & 0.038 & 0.691 & -1.991 & 2.036 & 28.300 & $<0.001$ & $<0.001$ & $<0.001$ \\
\hline Canada & 0.039 & 0.661 & -1.989 & 2.016 & 21.568 & $<0.001$ & $<0.001$ & $<0.001$ \\
\hline France & 0.049 & 0.884 & -2.072 & 2.972 & 40.174 & $<0.001$ & $<0.001$ & $<0.001$ \\
\hline Netherlands & 0.032 & 0.580 & -1.961 & 1.987 & 22.684 & $<0.001$ & $<0.001$ & $<0.001$ \\
\hline Hong Kong & 0.107 & 1.696 & -4.019 & 5.080 & 66.250 & $<0.001$ & $<0.001$ & $<0.001$ \\
\hline Spain & 0.035 & 0.645 & -1.996 & 2.004 & 27.165 & $<0.001$ & $<0.001$ & $<0.001$ \\
\hline Sweden & 0.028 & 0.540 & -1.030 & 1.990 & 19.818 & $<0.001$ & $<0.001$ & $<0.001$ \\
\hline Australia & 0.032 & 0.731 & -2.025 & 2.020 & 30.916 & $<0.001$ & $<0.001$ & $<0.001$ \\
\hline Italy & 0.018 & 0.905 & -2.042 & 2.968 & 36.404 & $<0.001$ & $<0.001$ & $<0.001$ \\
\hline \multicolumn{9}{|c|}{ Foreign Currency Futures } \\
\hline Euro & 0.016 & 6.968 & -18.139 & 18.108 & 98.384 & $<0.001$ & 0.027 & 0.143 \\
\hline Yen & -0.020 & 7.255 & -18.938 & 18.569 & 98.442 & $<0.001$ & $<0.001$ & 0.391 \\
\hline UK Pound & 0.119 & 5.615 & -14.298 & 14.189 & 98.211 & $<0.001$ & $<0.001$ & $<0.001$ \\
\hline Swiss Franc & 0.094 & 6.881 & -17.845 & 17.964 & 98.352 & $<0.001$ & $<0.001$ & 0.171 \\
\hline Canadian \$ & -0.159 & 4.289 & -11.116 & 11.198 & 98.282 & $<0.001$ & $<0.001$ & $<0.001$ \\
\hline
\end{tabular}


Table 2a

Contemporaneous Correlations of Quote Revisions on Eurodollar Futures Contracts, Exchange Traded Funds and Foreign Currency Futures Contracts

The top part of the table shows contemporaneous correlation coefficients of quote revisions on the Eurodollar futures contracts, the US Exchange Traded Fund, and the foreign currency futures contracts. The bottom part of the table shows the contemporaneous correlation coefficients of quote revisions on the US and foreign Exchange Traded Funds. The sources of the data are given in Table 1a.

\begin{tabular}{|c|c|c|c|c|c|c|c|c|c|c|}
\hline & \multicolumn{5}{|c|}{ Eurodollar futures } & \multirow{2}{*}{$\begin{array}{c}\text { US } \\
\text { ETF }\end{array}$} & \multicolumn{4}{|c|}{ Foreign Currency Futures } \\
\hline & $k=3$ & $k=6$ & $k=9$ & $k=12$ & $k=60$ & & Euro & Yen & UK Pd & Sw. Fr. \\
\hline \multicolumn{11}{|c|}{ Eurodollar futures } \\
\hline$k=3$ & 1 & & & & & & & & & \\
\hline$k=6$ & 0.773 & 1 & & & & & & & & \\
\hline$k=9$ & 0.733 & 0.873 & 1 & & & & & & & \\
\hline$k=12$ & 0.696 & 0.835 & 0.901 & 1 & & & & & & \\
\hline$k=60$ & 0.245 & 0.283 & 0.317 & 0.333 & 1 & & & & & \\
\hline US ETF & -0.157 & -0.168 & -0.157 & -0.154 & -0.010 & 1 & & & & \\
\hline \multicolumn{11}{|c|}{ Foreign Currency Futures } \\
\hline Euro & 0.177 & 0.167 & 0.161 & 0.152 & 0.044 & -0.309 & 1 & & & \\
\hline Yen & 0.102 & 0.086 & 0.068 & 0.054 & 0.008 & -0.186 & 0.379 & 1 & & \\
\hline UK Pd & 0.087 & 0.082 & 0.081 & 0.076 & 0.023 & -0.174 & 0.540 & 0.229 & 1 & \\
\hline Sw. Fr. & 0.221 & 0.204 & 0.184 & 0.172 & 0.058 & -0.325 & 0.883 & 0.396 & 0.496 & 1 \\
\hline $\operatorname{Cdn} \$$ & 0.022 & 0.017 & 0.025 & 0.026 & 0.033 & 0.100 & -0.014 & -0.005 & -0.005 & -0.024 \\
\hline
\end{tabular}

Exchange Traded Funds

\begin{tabular}{|c|c|c|c|c|c|c|c|c|c|c|c|c|}
\hline & US & Ger. & Jap. & UK & Swiss & Can. & Fra. & Neth & H.K. & Spain & Swe. & Aus. \\
\hline US & 1 & & & & & & & & & & & \\
\hline Germany & 0.196 & 1 & & & & & & & & & & \\
\hline Japan & 0.144 & 0.148 & 1 & & & & & & & & & \\
\hline UK & 0.176 & 0.209 & 0.110 & 1 & & & & & & & & \\
\hline Switzerland & 0.168 & 0.173 & 0.082 & 0.195 & 1 & & & & & & & \\
\hline Canada & 0.163 & 0.188 & 0.112 & 0.143 & 0.141 & 1 & & & & & & \\
\hline France & 0.215 & 0.404 & 0.156 & 0.226 & 0.200 & 0.233 & 1 & & & & & \\
\hline Netherlands & 0.228 & 0.224 & 0.099 & 0.244 & 0.300 & 0.138 & 0.241 & 1 & & & & \\
\hline Hong Kong & 0.204 & 0.166 & 0.145 & 0.201 & 0.145 & 0.158 & 0.167 & 0.182 & 1 & & & \\
\hline Spain & 0.262 & 0.259 & 0.120 & 0.257 & 0.288 & 0.171 & 0.297 & 0.401 & 0.193 & 1 & & \\
\hline Sweden & 0.251 & 0.197 & 0.101 & 0.225 & 0.256 & 0.143 & 0.219 & 0.352 & 0.167 & 0.345 & 1 & \\
\hline Australia & 0.113 & 0.168 & 0.101 & 0.145 & 0.108 & 0.147 & 0.171 & 0.144 & 0.140 & 0.176 & 0.073 & 1 \\
\hline Italy & 0.166 & 0.331 & 0.142 & 0.193 & 0.192 & 0.209 & 0.402 & 0.226 & 0.160 & 0.280 & 0.167 & 0.183 \\
\hline
\end{tabular}


Table 2b

Contemporaneous Correlations of Signed Order Flows of Eurodollar Futures Contracts, Exchange Traded Funds and Foreign Currency Futures Contracts

The top part of the table shows contemporaneous correlation coefficients of signed order flows of the Eurodollar futures contracts, the US Exchange Traded Fund, and the foreign currency futures contracts. The bottom part of the table shows the contemporaneous correlation coefficients of order flows of the US and foreign Exchange Traded Funds. The sources of the data are given in Table $1 \mathrm{~b}$.

\begin{tabular}{|c|c|c|c|c|c|c|c|c|c|c|}
\hline & \multicolumn{5}{|c|}{ Eurodollar futures } & \multirow{2}{*}{$\begin{array}{c}\text { US } \\
\text { ETF }\end{array}$} & \multicolumn{4}{|c|}{ Foreign Currency Futures } \\
\hline & $k=3$ & $k=6$ & $k=9$ & $k=12$ & $k=60$ & & Euro & Yen & UK Pd & Sw. Fr. \\
\hline \multicolumn{11}{|c|}{ Eurodollar futures } \\
\hline$k=3$ & 1 & & & & & & & & & \\
\hline$k=6$ & 0.672 & 1 & & & & & & & & \\
\hline$k=9$ & 0.647 & 0.814 & 1 & & & & & & & \\
\hline$k=12$ & 0.619 & 0.774 & 0.836 & 1 & & & & & & \\
\hline$k=60$ & 0.185 & 0.239 & 0.267 & 0.285 & 1 & & & & & \\
\hline US ETF & -0.121 & -0.122 & -0.114 & -0.113 & 0.006 & 1 & & & & \\
\hline \multicolumn{11}{|c|}{ Foreign Currency Futures } \\
\hline Euro & 0.056 & 0.060 & 0.067 & 0.055 & 0.001 & -0.092 & 1 & & & \\
\hline Yen & 0.008 & 0.015 & 0.006 & 0.004 & -0.016 & -0.027 & 0.158 & 1 & & \\
\hline UK Pd & 0.027 & 0.031 & 0.029 & 0.033 & 0.001 & -0.046 & 0.216 & 0.061 & 1 & \\
\hline Sw. Fr. & 0.035 & 0.031 & 0.035 & 0.030 & -0.012 & -0.062 & 0.292 & 0.110 & 0.152 & 1 \\
\hline $\mathrm{Cdn} \$$ & 0.014 & 0.008 & 0.007 & 0.010 & 0.020 & 0.024 & -0.014 & 0.003 & -0.018 & -0.020 \\
\hline
\end{tabular}

Exchange Traded Funds

\begin{tabular}{lcccccccccccc} 
& US & Ger. & Jap. & UK & Swiss & Can. & Fra. & Neth & H.K. & Spain & Swe. & Aus. \\
\hline US & 1 & & & & & & & & & & & \\
Germany & 0.058 & 1 & & & & & & & & & \\
Japan & 0.044 & 0.094 & 1 & & & & & & & & \\
UK & 0.050 & 0.172 & 0.091 & 1 & & & & & & & \\
Switzerland & 0.037 & 0.155 & 0.058 & 0.161 & 1 & & & & & & \\
Canada & 0.033 & 0.066 & 0.054 & 0.040 & 0.051 & 1 & & & & & \\
France & 0.055 & 0.256 & 0.093 & 0.188 & 0.158 & 0.053 & 1 & & & & \\
Netherlands & 0.024 & 0.126 & 0.047 & 0.131 & 0.209 & 0.040 & 0.196 & 1 & & & \\
Hong Kong & 0.064 & 0.083 & 0.088 & 0.067 & 0.066 & 0.027 & 0.079 & 0.049 & 1 & & \\
Spain & 0.027 & 0.121 & 0.064 & 0.117 & 0.140 & 0.033 & 0.180 & 0.186 & 0.069 & 1 & \\
Sweden & 0.010 & 0.098 & 0.043 & 0.085 & 0.125 & 0.042 & 0.135 & 0.148 & 0.040 & 0.151 & 1 & \\
Australia & 0.017 & 0.079 & 0.070 & 0.100 & 0.094 & 0.080 & 0.084 & 0.096 & 0.065 & 0.877 & 0.060 & 1 \\
Italy & 0.040 & 0.155 & 0.053 & 0.106 & 0.141 & 0.034 & 0.213 & 0.172 & 0.062 & 0.221 & 0.097 & 0.086
\end{tabular}




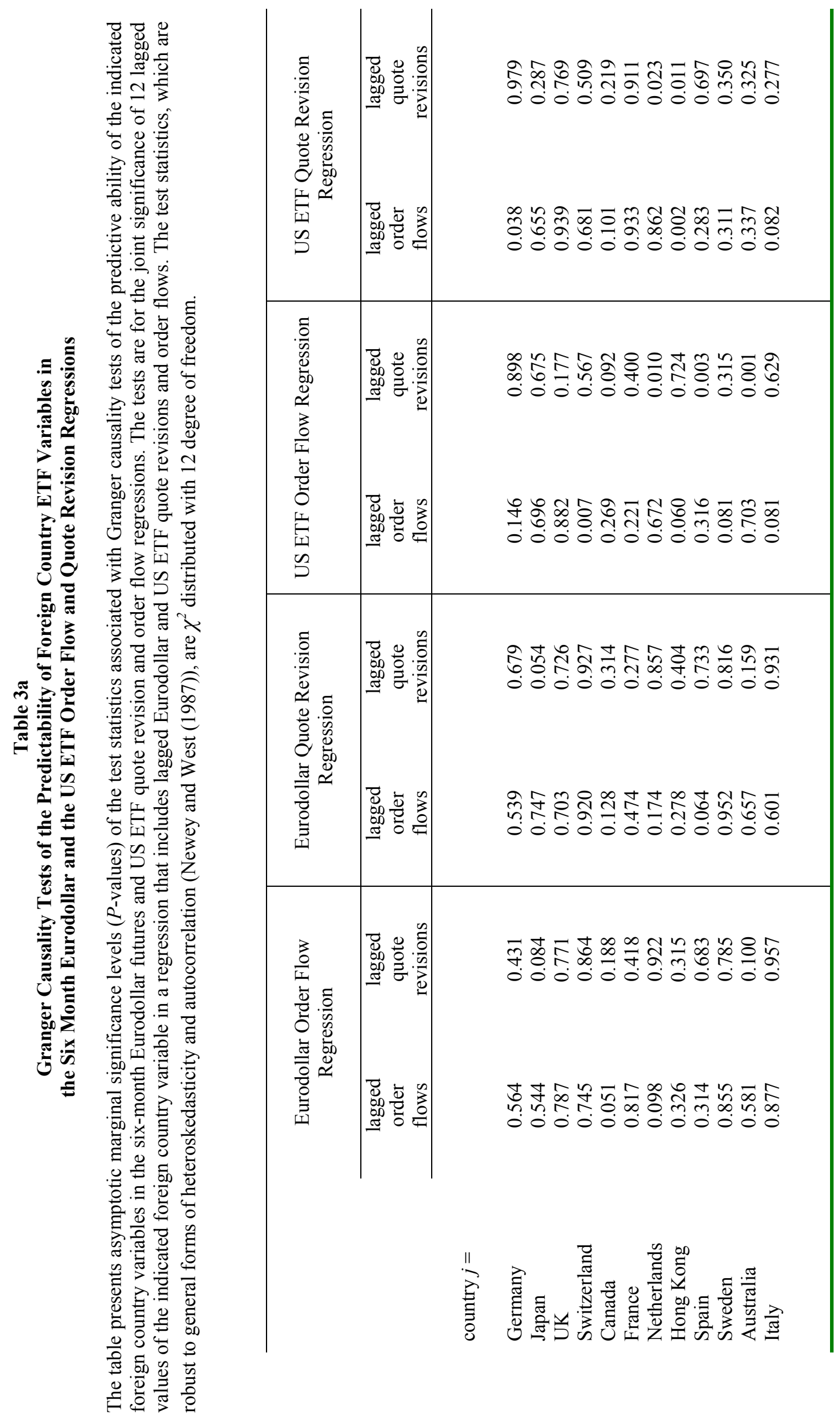


Table 3b

\section{Granger Causality Tests of the Predictability of the Six-Month Eurodollar and US ETF Variables in the Foreign Country ETF Order Flow and Quote Revision Regressions}

The table presents asymptotic marginal significance levels ( $P$-values) of the test statistics associated with Granger causality tests of the predictive ability of the indicated US ETF variables in the foreign country quote revision and order flow regressions. The left-hand-side variable of the regression is indicated at the top of the table. Each of the regressions includes the lagged order flows and quote revisions from country $j$. The tests are for the joint significance of the lagged values of the indicated Eurodollar or US ETF variable. The test statistics, which are robust to general forms of heteroskedasticity and autocorrelation (Newey and West (1987)), are $\chi^{2}$ distributed with 12 degree of freedom.

\begin{tabular}{|c|c|c|c|c|c|c|c|c|}
\hline & \multicolumn{4}{|c|}{ Country-j ETF Order Flow Regressions } & \multicolumn{4}{|c|}{ Country-j ETF Quote Revision Regressions } \\
\hline & \multicolumn{2}{|c|}{ Eurodollar } & \multicolumn{2}{|c|}{ US ETF } & \multicolumn{2}{|c|}{ Eurodollar } & \multicolumn{2}{|c|}{ US ETF } \\
\hline & $\begin{array}{c}\text { lagged } \\
\text { order } \\
\text { flows }\end{array}$ & $\begin{array}{l}\text { lagged } \\
\text { quote } \\
\text { revisions }\end{array}$ & $\begin{array}{c}\text { lagged } \\
\text { order } \\
\text { flows }\end{array}$ & $\begin{array}{l}\text { lagged } \\
\text { quote } \\
\text { revisions }\end{array}$ & $\begin{array}{c}\text { lagged } \\
\text { order } \\
\text { flows }\end{array}$ & $\begin{array}{c}\text { lagged } \\
\text { quote } \\
\text { revisions }\end{array}$ & $\begin{array}{c}\text { lagged } \\
\text { order } \\
\text { flows }\end{array}$ & $\begin{array}{c}\text { lagged } \\
\text { quote } \\
\text { revisions }\end{array}$ \\
\hline country $j=$ & & & & & & & & \\
\hline Germany & 0.078 & 0.007 & 0.046 & $<0.001$ & $<0.001$ & $<0.001$ & 0.263 & $<0.001$ \\
\hline Japan & $<0.001$ & $<0.001$ & 0.690 & $<0.001$ & $<0.001$ & $<0.001$ & 0.078 & $<0.001$ \\
\hline $\mathrm{UK}$ & 0.113 & 0.001 & 0.274 & $<0.001$ & $<0.001$ & $<0.001$ & 0.954 & $<0.001$ \\
\hline Switzerland & 0.081 & 0.066 & 0.060 & 0.297 & 0.085 & $<0.001$ & 0.041 & $<0.001$ \\
\hline Canada & 0.350 & 0.096 & 0.435 & $<0.001$ & $<0.001$ & $<0.001$ & 0.542 & $<0.001$ \\
\hline France & 0.504 & 0.332 & 0.188 & $<0.001$ & 0.291 & 0.158 & 0.826 & $<0.001$ \\
\hline Netherlands & 0.004 & $<0.001$ & 0.011 & 0.070 & 0.105 & 0.544 & 0.629 & $<0.001$ \\
\hline Hong Kong & 0.285 & 0.201 & 0.053 & $<0.001$ & $<0.001$ & $<0.001$ & 0.530 & $<0.001$ \\
\hline Spain & 0.901 & 0.737 & 0.009 & $<0.001$ & $<0.001$ & $<0.001$ & 0.916 & $<0.001$ \\
\hline Sweden & 0.004 & $<0.001$ & 0.355 & 0.472 & 0.369 & 0.089 & 0.017 & $<0.001$ \\
\hline Australia & 0.023 & $<0.001$ & 0.741 & $<0.001$ & 0.002 & 0.005 & 0.112 & $<0.001$ \\
\hline Italy & 0.114 & 0.135 & 0.811 & $<0.001$ & 0.157 & 0.156 & 0.372 & $<0.001$ \\
\hline
\end{tabular}


Table 4

\section{Cochrane-Piazzesi (2002) Regressions using Eurodollar Futures Contracts}

The table provides estimates of the Cochrane and Piazzesi (2002) regressions to model the relationship between the Eurodollar futures contract and future monetary policy changes. The dependent variable in all of the regressions is the change in the "price" of the Federal funds target $\left(\Delta P_{\tau}^{T R}{ }_{\tau}\right.$ ), when a target change occurs. Note that an increase in this variable implies a decrease in the target rate. The independent variables are the lagged level of the Federal funds target rate price $\left(P^{T R}{ }_{\tau-1}\right)$ and the spread between the log target-rate shadow price and the $j$-month $\log$ Eurodollar futures price $\left(S P_{\tau-1}=P_{\tau-1}^{T R}-P_{\tau-1}^{E D}\right)$. These latter two variables are recorded 30-minutes before the target-rate change. The sample period is from April 1, 1996 to November 30, 2001. The time index is in event time: $\tau=1, \ldots 20$, as there were 20 target-rate changes in this period. The White $t$ statistics (in parentheses) are asymptotically robust to general forms of heteroskedasticity. The $R^{2}$ statistics are adjusted for degrees of freedom.

\begin{tabular}{|c|c|c|c|}
\hline futures contract maturity & $\begin{array}{c}P^{T R}{ }_{\tau-1} \\
\text { (t-stat.) }\end{array}$ & $\begin{array}{c}S P_{\tau-1} \\
\text { (t-stat.) }\end{array}$ & $R^{2}$ \\
\hline$k=3$ & $\begin{array}{c}0.055 \\
(2.840)\end{array}$ & $\begin{array}{c}-0.518 \\
(-15.410)\end{array}$ & 0.910 \\
\hline$k=6$ & $\begin{array}{c}0.091 \\
(5.216)\end{array}$ & $\begin{array}{c}-0.383 \\
(-15.844)\end{array}$ & 0.920 \\
\hline$k=9$ & $\begin{array}{c}0.119 \\
(5.988)\end{array}$ & $\begin{array}{c}-0.347 \\
(-12.717)\end{array}$ & 0.878 \\
\hline$k=12$ & $\begin{array}{c}0.152 \\
(6.520)\end{array}$ & $\begin{array}{c}-0.334 \\
(-10.023)\end{array}$ & 0.857 \\
\hline$k=60$ & $\begin{array}{c}0.397 \\
(7.823)\end{array}$ & $\begin{array}{c}-0.380 \\
(-4.982)\end{array}$ & 0.628 \\
\hline
\end{tabular}


Table 5a

Estimates of the Modified Hasbrouck (1991) Model for the Eurodollar Futures and US Exchange Traded Fund Order Flow Regressions

The table presents the results from OLS regressions of the six-month Eurodollar futures signed order flow (7) and the US ETF signed order flow (8) on the selected public information variables. The signed order flows on the two assets are accumulated over a one-half-hour interval. They are projected on 12 lagged values each of the Eurodollar and the US ETF order flows and quote revisions. For these variables the sum of the 12 coefficients is given along with a $t$ statistic of the significance of the sum. The regressions also include: the lagged Federal Funds target price $\left(P^{T R}{ }_{t-1}\right)$; and the lagged difference between the Fed Funds target price and the price of the Eurodollar contract $\left(S P_{t-1}=P_{t-1}^{T R}-P_{t-1}^{E D}\right)$. The Newey-West $t$ statistics (in parentheses) are asymptotically robust to general forms of heteroskedasticity and autocorrelation. The $R^{2}$ statistics are adjusted for degrees of freedom.

\begin{tabular}{|c|c|c|c|c|c|c|}
\hline \multicolumn{2}{|c|}{ Eurodollar } & \multicolumn{2}{|c|}{ US ETF } & \multicolumn{2}{|c|}{ monetary policy } & \\
\hline $\begin{array}{l}\text { lagged } \\
\text { order } \\
\text { flows } \\
\text { ( } t \text {-stat.) }\end{array}$ & $\begin{array}{l}\text { lagged } \\
\text { quote } \\
\text { revisions } \\
\text { (t-stat.) }\end{array}$ & $\begin{array}{l}\text { lagged } \\
\text { order } \\
\text { flows } \\
\text { ( } t \text {-stat.) }\end{array}$ & $\begin{array}{l}\text { lagged } \\
\text { quote } \\
\text { revisions } \\
(t \text {-stat.) }\end{array}$ & $\begin{array}{c}P_{t-1}^{T R} \\
\text { (t-stat.) }\end{array}$ & $\begin{array}{c}S P_{t-1} \\
\text { (t-stat.) }\end{array}$ & $R^{2}$ \\
\hline
\end{tabular}

Eurodollar Order Flow Regression

$\begin{array}{ccccccc}0.029 & 2.148 & 0.001 & 0.134 & -0.016 & -0.022 & 0.006 \\ (0.480) & (0.224) & (0.320) & (0.561) & (-0.640) & (-0.501) & \end{array}$

$\underline{\text { US ETF Order Flow Regression }}$

$\begin{array}{ccccccc}-0.041 & 216.576 & 0.371 & -6.749 & -0.953 & 1.080 & 0.068 \\ (-0.094) & (3.325) & (12.001) & (-3.664) & (-5.310) & (3.791) & \end{array}$




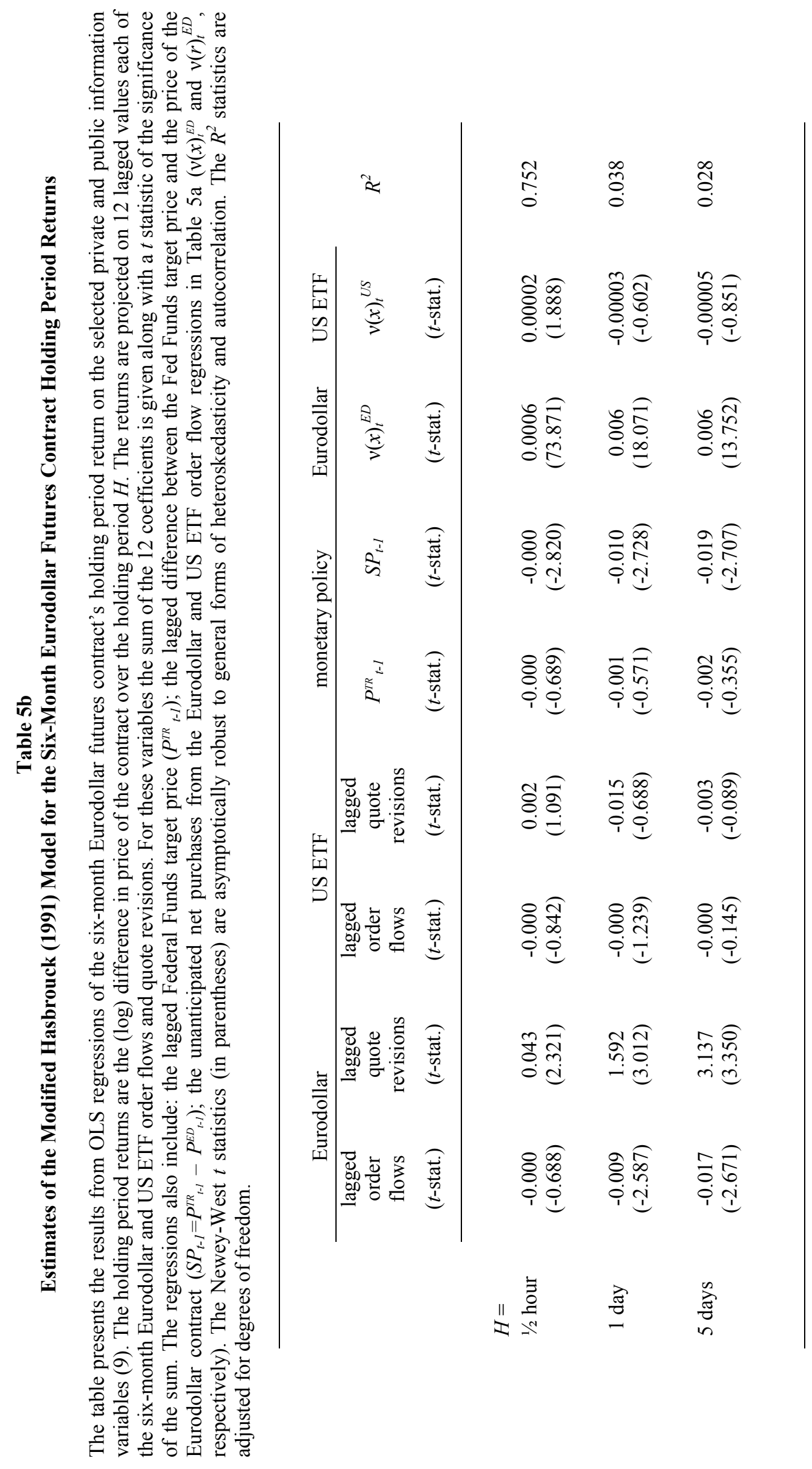




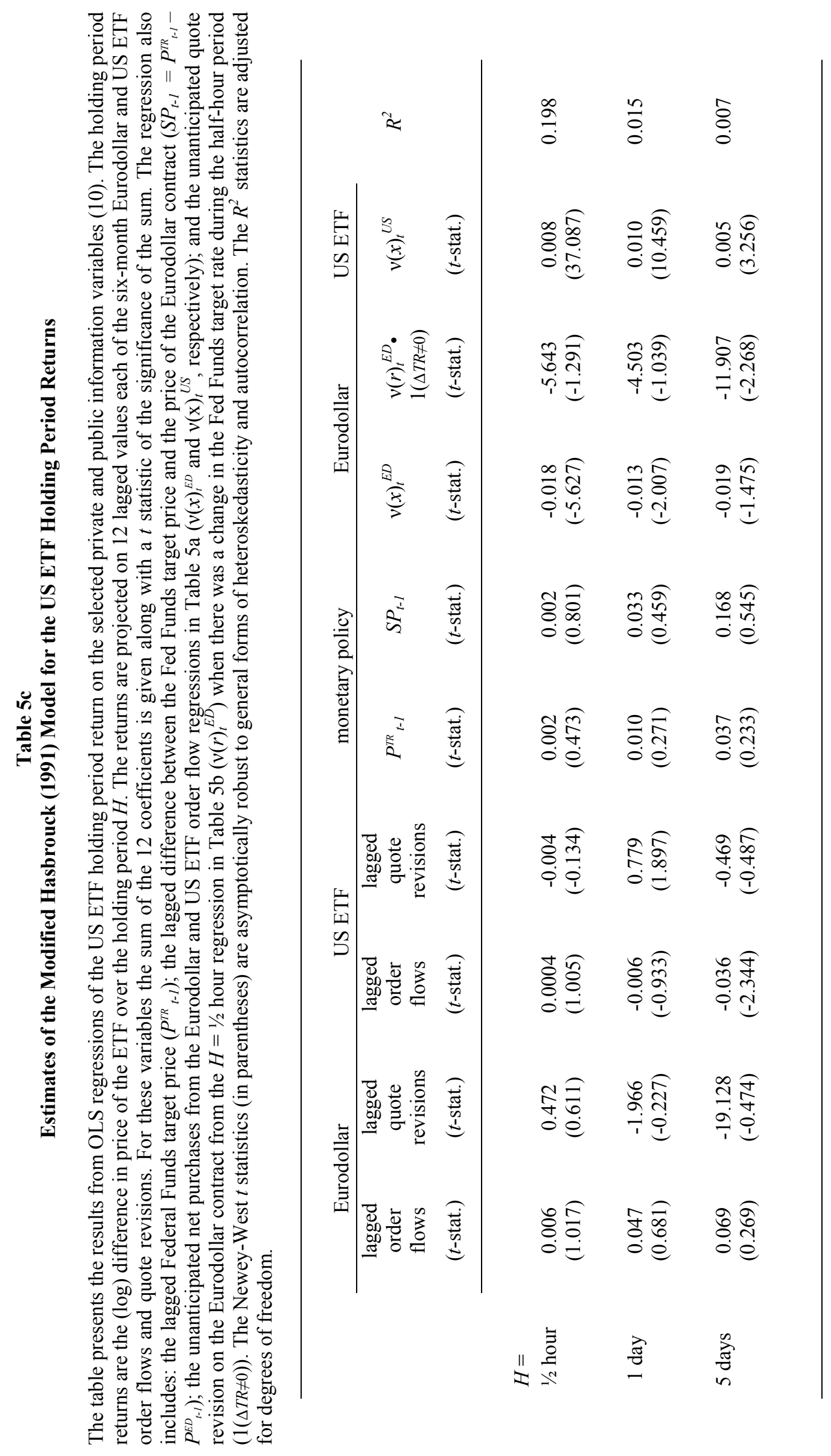


Table 6

Summary Statistics from and Tests of the Two Latent Factors Model of International Stock Returns

The top part of the table presents the value of the $J$-statistics associated with the Wald tests of the overidentifying restrictions of the two latent factor model of international stock returns. The statistics are distributed as $\chi^{2}(60)$ and are presented along with their asymptotic marginal significance levels ( $P$-value). The model is estimated separately for each holding period $H$ by Generalized Method of Moments. The bottom part of the table presents variance ratio measures of the statistical fit of the model. The ratio shows how the two latent factor model captures the expected return variation in the data. The numerator is the variance of the expected return on the foreign ETF from the latent variable model while the denominator is the variance of the expected return from an OLS regression of the foreign ETF return on the global instruments.

\begin{tabular}{llll}
\hline & & & \\
& & & \\
& & & \\
& & & \\
& -statistic model test & & \\
\hline & & & \\
$\chi^{2}(60)$ statistic & 109.62 & 73.26 & 60.93 \\
$P$-value & $<0.001$ & 0.117 & 0.442 \\
& & & \\
Variance ratios & & & \\
& & & \\
Germany & & & \\
Japan & 0.912 & 0.929 & 0.806 \\
UK & 0.813 & 0.698 & 1.386 \\
Switzerland & 0.909 & 0.935 & 0.432 \\
Canada & 0.875 & 0.912 & 0.686 \\
France & 0.866 & 0.883 & 0.720 \\
Netherlands & 0.927 & 0.944 & 0.538 \\
Hong Kong & 0.929 & 0.911 & 0.823 \\
Spain & 0.921 & 0.814 & 0.417 \\
Sweden & 0.932 & 0.982 & 0.828 \\
Australia & 0.938 & 0.840 & 0.531 \\
Italy & 0.939 & 0.921 & 0.274 \\
& 0.945 & 0.981 & 0.862 \\
\hline
\end{tabular}


Table 7

\section{Beta Coefficients on the Implied Global Risk Premiums in the Two Latent Factors Model of International Stock Returns}

The table shows the $\beta$ coefficients on the implied global risk premiums from the latent factor model of international stock returns. The two implied global risk premiums are the linear combination of the global instruments given in Table 8. The beta coefficients for Germany and Japan are normalized for identification. The model is estimated separately for each holding period $H$ by Generalized Method of Moments. The Newey-West $t$ statistics (in parentheses) are asymptotically robust to general forms of heteroskedasticity and autocorrelation.

\begin{tabular}{|c|c|c|c|c|c|c|}
\hline & \multicolumn{2}{|c|}{$H=1 / 2$ hour } & \multicolumn{2}{|c|}{$H=1$ day } & \multicolumn{2}{|c|}{$H=5$ days } \\
\hline & $\begin{array}{c}\beta(1) \\
(t \text {-stat. })\end{array}$ & $\begin{array}{c}\beta(2) \\
(t \text {-stat. })\end{array}$ & $\begin{array}{c}\beta(1) \\
(t \text {-stat. })\end{array}$ & $\begin{array}{c}\beta(2) \\
(t \text {-stat. })\end{array}$ & $\begin{array}{c}\beta(1) \\
(t \text {-stat. })\end{array}$ & $\begin{array}{c}\beta(2) \\
(t \text {-stat. })\end{array}$ \\
\hline Germany & 1.000 & 0.000 & 1.000 & 0.000 & 1.000 & 0.000 \\
\hline Japan & 0.000 & 1.000 & 0.000 & 1.000 & 0.000 & 1.000 \\
\hline UK & $\begin{array}{c}0.495 \\
(6.593)\end{array}$ & $\begin{array}{c}0.523 \\
(3.010)\end{array}$ & $\begin{array}{c}0.315 \\
(1.444)\end{array}$ & $\begin{array}{c}0.905 \\
(1.736)\end{array}$ & $\begin{array}{c}0.988 \\
(3.914)\end{array}$ & $\begin{array}{c}-0.803 \\
(-1.299)\end{array}$ \\
\hline Switzerland & $\begin{array}{c}-0.086 \\
(-0.666)\end{array}$ & $\begin{array}{c}1.106 \\
(4.370)\end{array}$ & $\begin{array}{l}-0.234 \\
(0.696)\end{array}$ & $\begin{array}{c}1.661 \\
(2.017)\end{array}$ & $\begin{array}{l}1.416 \\
(2.963)\end{array}$ & $\begin{array}{c}-1.689 \\
(-1.472)\end{array}$ \\
\hline Canada & $\begin{array}{c}0.488 \\
(2.516)\end{array}$ & $\begin{array}{c}0.535 \\
(1.726)\end{array}$ & $\begin{array}{c}-1.220 \\
(-0.978)\end{array}$ & $\begin{array}{c}4.856 \\
(1.684)\end{array}$ & $\begin{array}{c}0.713 \\
(2.747)\end{array}$ & $\begin{array}{c}0.993 \\
(1.344)\end{array}$ \\
\hline France & $\begin{array}{c}0.887 \\
(15.246)\end{array}$ & $\begin{array}{c}0.099 \\
(0.710)\end{array}$ & $\begin{array}{c}0.971 \\
(8.029)\end{array}$ & $\begin{array}{c}-0.036 \\
(-0.118)\end{array}$ & $\begin{array}{c}1.316 \\
(5.082)\end{array}$ & $\begin{array}{c}-0.916 \\
(-1.377)\end{array}$ \\
\hline Netherlands & $\begin{array}{c}0.466 \\
(5.153)\end{array}$ & $\begin{array}{c}0.727 \\
(3.501)\end{array}$ & $\begin{array}{c}0.906 \\
(6.965)\end{array}$ & $\begin{array}{c}-0.207 \\
(-0.620)\end{array}$ & $\begin{array}{c}1.886 \\
(3.822)\end{array}$ & $\begin{array}{c}-2.050 \\
(-1.602)\end{array}$ \\
\hline Hong Kong & $\begin{array}{c}0.860 \\
(4.628)\end{array}$ & $\begin{array}{c}1.019 \\
(2.769)\end{array}$ & $\begin{array}{c}0.832 \\
(3.092)\end{array}$ & $\begin{array}{c}0.421 \\
(0.642)\end{array}$ & $\begin{array}{c}2.061 \\
(3.330)\end{array}$ & $\begin{array}{c}-1.635 \\
(-1.081)\end{array}$ \\
\hline Spain & $\begin{array}{c}0.749 \\
(8.713)\end{array}$ & $\begin{array}{c}0.766 \\
(3.727)\end{array}$ & $\begin{array}{c}1.518 \\
(4.529)\end{array}$ & $\begin{array}{c}-1.255 \\
(-1.452)\end{array}$ & $\begin{array}{c}2.090 \\
(3.190)\end{array}$ & $\begin{array}{c}-2.632 \\
(-1.565)\end{array}$ \\
\hline Sweden & $\begin{array}{c}-1.211 \\
(-4.618)\end{array}$ & $\begin{array}{c}3.485 \\
(5.852)\end{array}$ & $\begin{array}{c}-0.927 \\
(-0.732)\end{array}$ & $\begin{array}{c}4.606 \\
(1.597)\end{array}$ & $\begin{array}{c}0.572 \\
(1.809)\end{array}$ & $\begin{array}{c}1.484 \\
(1.575)\end{array}$ \\
\hline Australia & $\begin{array}{c}2.963 \\
(9.167)\end{array}$ & $\begin{array}{c}-3.141 \\
(-4.816)\end{array}$ & $\begin{array}{c}2.630 \\
(2.794)\end{array}$ & $\begin{array}{c}-4.090 \\
(-1.772)\end{array}$ & $\begin{array}{c}1.433 \\
(3.728)\end{array}$ & $\begin{array}{l}-1.799 \\
(-1.592)\end{array}$ \\
\hline Italy & $\begin{array}{c}1.413 \\
(14.094)\end{array}$ & $\begin{array}{c}-0.774 \\
(-3.365)\end{array}$ & $\begin{array}{c}2.879 \\
(2.910)\end{array}$ & $\begin{array}{c}-4.087 \\
(-1.738)\end{array}$ & $\begin{array}{c}2.207 \\
(3.820)\end{array}$ & $\begin{array}{c}-2.411 \\
(-1.582)\end{array}$ \\
\hline
\end{tabular}


Table 8

\section{Coefficients on the Global Instruments in the Two Latent Factors Model of International Stock Returns}

The table shows the $\alpha_{H}$ coefficients on the global instruments in the latent factor model of international stock returns. The global instruments are: a constant; the lagged Federal funds target price $\left(P_{t-1}^{T R}\right)$; the lagged difference between the Fed Funds target price and the price of the Eurodollar contract $\left(S P_{t-1}=P_{t-1}^{T R}-P_{t-1}^{E D}\right.$; the unanticipated net purchases on the six-month Eurodollar contract from Table $5 \mathrm{a}\left(\mathrm{v}(x)_{t}^{E D}\right)$; the unanticipated quote revision on the Eurodollar contract from the $H=1 / 2$ hour regression in Table $5 \mathrm{~b}\left(v(r)_{t}^{E D}\right)$ which are separated into whether there was a change in the Fed Funds target rate during the half-hour period $(1(\Delta T R \neq 0))$ or not; and the unanticipated net purchases and quote revisions on the US ETF from Tables 5a and $5 \mathrm{c}\left(v(x)_{t}^{U S}\right.$ and $\left.v(r)_{t}^{U S}\right)$. The model is estimated separately by Generalized Method of Moments for each holding period $H$. The Newey-West $t$ statistics (in parentheses) are asymptotically robust to general forms of heteroskedasticity and autocorrelation. The $\sigma$-shocks [in brackets] represent the effect of a one standard deviation shock to the indicated variable, normalized by the standard deviation of the latent factor.

\begin{tabular}{|c|c|c|c|c|c|c|c|c|}
\hline \multirow[b]{2}{*}{$\begin{array}{l}\text { latent } \\
\text { factor }\end{array}$} & \multirow[b]{2}{*}{$\begin{array}{l}\text { constant } \\
\text { (t-stat.) }\end{array}$} & \multicolumn{2}{|c|}{ monetary policy } & \multicolumn{3}{|c|}{ Eurodollar } & \multicolumn{2}{|c|}{ US ETF } \\
\hline & & $\begin{array}{c}P_{t-1}^{T R} \\
(t \text {-stat. }) \\
{[\sigma \text {-shock }]}\end{array}$ & $\begin{array}{c}S P_{t-1} \\
(t \text {-stat. }) \\
{[\sigma \text {-shock }]}\end{array}$ & $\begin{array}{c}v(x)_{t}^{E D} \\
(t \text {-stat. }) \\
{[\sigma \text {-shock }]}\end{array}$ & $\begin{array}{c}v(r)_{t}^{E D} \bullet \\
1(\Delta T R=0) \\
(t \text {-stat. }) \\
{[\sigma \text {-shock] }}\end{array}$ & $\begin{array}{c}v(r)_{t}^{E D} \cdot \\
1(\Delta T R \neq 0) \\
(t \text {-stat. }) \\
{[\sigma \text {-shock] }}\end{array}$ & $\begin{array}{c}v(x)_{t}^{U S} \\
(t \text {-stat. }) \\
{[\sigma \text {-shock }]}\end{array}$ & $\begin{array}{c}v(r)_{t}^{U S} \\
(t \text {-stat. }) \\
{[\sigma \text {-shock }]}\end{array}$ \\
\hline \multicolumn{9}{|c|}{$H=1 / 2$ hour } \\
\hline 1. & $\begin{array}{c}-0.878 \\
(-1.511)\end{array}$ & $\begin{array}{c}0.002 \\
(1.513) \\
{[0.025]}\end{array}$ & $\begin{array}{c}-0.005 \\
(-2.455) \\
{[0.041]}\end{array}$ & $\begin{array}{c}-0.002 \\
(-2.748) \\
{[0.069]}\end{array}$ & $\begin{array}{c}-0.251 \\
(-0.840) \\
{[0.014]}\end{array}$ & $\begin{array}{c}-10.128 \\
(-5.250) \\
{[0.789]}\end{array}$ & $\begin{array}{c}0.001 \\
(10.234) \\
{[0.227]}\end{array}$ & $\begin{array}{c}0.152 \\
(11.572) \\
{[0.569]}\end{array}$ \\
\hline 2. & $\begin{array}{c}-0.812 \\
(-1.812)\end{array}$ & $\begin{array}{c}0.002 \\
(1.815) \\
{[0.039]}\end{array}$ & $\begin{array}{c}-0.003 \\
(-1.531) \\
{[0.034]}\end{array}$ & $\begin{array}{c}-0.003 \\
(-4.400) \\
{[0.141]}\end{array}$ & $\begin{array}{c}-0.334 \\
(-1.386) \\
{[0.032]}\end{array}$ & $\begin{array}{c}-3.982 \\
(-3.433) \\
{[0.521]}\end{array}$ & $\begin{array}{c}0.001 \\
(8.843) \\
{[0.333]}\end{array}$ & $\begin{array}{c}0.122 \\
(11.251) \\
{[0.769]}\end{array}$ \\
\hline \multicolumn{9}{|c|}{$H=1$ day } \\
\hline 1. & $\begin{array}{c}-3.308 \\
(-0.214)\end{array}$ & $\begin{array}{c}0.007 \\
(0.216) \\
{[0.029]}\end{array}$ & $\begin{array}{c}0.007 \\
(0.127) \\
{[0.017]}\end{array}$ & $\begin{array}{c}-0.013 \\
(-2.297) \\
{[0.113]}\end{array}$ & $\begin{array}{c}0.899 \\
(0.436) \\
{[0.015]}\end{array}$ & $\begin{array}{c}-11.194 \\
(-8.891) \\
{[0.261]}\end{array}$ & $\begin{array}{c}0.008 \\
(9.042) \\
{[0.506]}\end{array}$ & $\begin{array}{c}0.721 \\
(12.337) \\
{[0.807]}\end{array}$ \\
\hline 2. & $\begin{array}{c}-3.481 \\
(-0.463)\end{array}$ & $\begin{array}{c}0.008 \\
(0.464) \\
{[0.062]}\end{array}$ & $\begin{array}{c}0.018 \\
(0.584) \\
{[0.086]}\end{array}$ & $\begin{array}{c}-0.008 \\
(-2.483) \\
{[0.141]}\end{array}$ & $\begin{array}{c}-0.325 \\
(-0.302) \\
{[0.011]}\end{array}$ & $\begin{array}{c}-3.543 \\
(-6.197) \\
{[0.171]}\end{array}$ & $\begin{array}{c}0.004 \\
(5.950) \\
{[0.507]}\end{array}$ & $\begin{array}{c}0.353 \\
(6.555) \\
{[0.819]}\end{array}$ \\
\hline \multicolumn{9}{|c|}{$H=5$ days } \\
\hline 1. & $\begin{array}{l}-55.712 \\
(-0.893)\end{array}$ & $\begin{array}{c}0.122 \\
(0.892) \\
{[0.422]}\end{array}$ & $\begin{array}{c}0.296 \\
(1.319) \\
{[0.624]}\end{array}$ & $\begin{array}{c}-0.030 \\
(-2.595) \\
{[0.244]}\end{array}$ & $\begin{array}{c}4.876 \\
(1.306) \\
{[0.075]}\end{array}$ & $\begin{array}{c}-8.692 \\
(-3.964) \\
{[0.184]}\end{array}$ & $\begin{array}{c}0.003 \\
(2.291) \\
{[0.174]}\end{array}$ & $\begin{array}{c}0.592 \\
(5.835) \\
{[0.600]}\end{array}$ \\
\hline 2. & $\begin{array}{l}-67.328 \\
(-1.679)\end{array}$ & $\begin{array}{c}0.148 \\
(1.678) \\
{[0.582]}\end{array}$ & $\begin{array}{c}0.335 \\
(1.864) \\
{[0.807]}\end{array}$ & $\begin{array}{c}-0.021 \\
(-2.232) \\
{[0.191]}\end{array}$ & $\begin{array}{c}2.444 \\
(1.122) \\
{[0.043]}\end{array}$ & $\begin{array}{c}-1.329 \\
(-1.445) \\
{[0.032]}\end{array}$ & $\begin{array}{c}0.002 \\
(1.899) \\
{[0.103]}\end{array}$ & $\begin{array}{c}0.267 \\
(2.885) \\
{[0.308]}\end{array}$ \\
\hline
\end{tabular}


Table 9

Estimates of the Order Flow Regressions for the Foreign ETFs

The table presents the results from OLS regressions of the order flows of the foreign ETFs on: the lagged change in the Federal Funds target price $\left(P^{T R}{ }_{t-1}\right)$; the lagged difference between the Fed Funds target price and the price of the Eurodollar contract $\left(S P_{t-1}=P_{t-1}^{T R}-P_{t-1}^{E D}\right)$; the unanticipated net purchases from the Eurodollar order flow regression in Table 5a $\left(v(x)_{t}^{E D}\right)$; and the unanticipated net purchases from the US ETF order flow regression in Table 5a $\left(v(x)_{t}^{U S}\right)$. The regressions also include 12 lagged values each of the order flows and quote revisions of the six-month Eurodollar futures contract, the US ETF and the foreign ETF as well as a constant. The NeweyWest $t$ statistics (in parentheses) are asymptotically robust to general forms of heteroskedasticity and autocorrelation. The $R^{2}$ statistics are adjusted for degrees of freedom.

\begin{tabular}{|c|c|c|c|c|c|}
\hline & \multicolumn{2}{|c|}{ monetary policy } & \multirow{2}{*}{$\begin{array}{c}\text { Eurodollar } \\
v(x)_{t}^{E D} \\
(t \text {-stat. })\end{array}$} & \multirow{2}{*}{$\begin{array}{l}\text { US ETF } \\
v(x)_{t}^{U S} \\
(t \text {-stat. })\end{array}$} & \multirow[b]{2}{*}{$R^{2}$} \\
\hline & $\begin{array}{c}P^{T R}{ }_{t-1} \\
(t \text {-stat. })\end{array}$ & $\begin{array}{c}S P_{t-1} \\
(t \text {-stat. })\end{array}$ & & & \\
\hline Germany & $\begin{array}{c}-0.092 \\
(-6.375)\end{array}$ & $\begin{array}{c}0.100 \\
(4.250)\end{array}$ & $\begin{array}{c}-0.018 \\
(-2.984)\end{array}$ & $\begin{array}{c}0.004 \\
(5.287)\end{array}$ & 0.094 \\
\hline Japan & $\begin{array}{c}0.066 \\
(2.470)\end{array}$ & $\begin{array}{c}0.044 \\
(1.003)\end{array}$ & $\begin{array}{c}-0.038 \\
(-3.406)\end{array}$ & $\begin{array}{c}0.009 \\
(5.842)\end{array}$ & 0.178 \\
\hline UK & $\begin{array}{c}-0.060 \\
(-5.625)\end{array}$ & $\begin{array}{c}0.091 \\
(5.220)\end{array}$ & $\begin{array}{c}-0.012 \\
(-2.784)\end{array}$ & $\begin{array}{c}0.003 \\
(5.300)\end{array}$ & 0.089 \\
\hline Switzerland & $\begin{array}{c}-0.025 \\
(-3.683)\end{array}$ & $\begin{array}{c}0.014 \\
(1.238)\end{array}$ & $\begin{array}{c}-0.001 \\
(-0.310)\end{array}$ & $\begin{array}{c}0.001 \\
(3.196)\end{array}$ & 0.019 \\
\hline Canada & $\begin{array}{c}-0.007 \\
(-1.086)\end{array}$ & $\begin{array}{c}-0.018 \\
(-1.707)\end{array}$ & $\begin{array}{c}-0.003 \\
(-0.962)\end{array}$ & $\begin{array}{c}0.002 \\
(4.563)\end{array}$ & 0.041 \\
\hline France & $\begin{array}{c}-0.032 \\
(-3.732)\end{array}$ & $\begin{array}{c}0.084 \\
(5.907)\end{array}$ & $\begin{array}{c}-0.006 \\
(-1.804)\end{array}$ & $\begin{array}{c}0.003 \\
(5.936)\end{array}$ & 0.037 \\
\hline Netherlands & $\begin{array}{c}-0.007 \\
(-1.240)\end{array}$ & $\begin{array}{c}0.019 \\
(2.021)\end{array}$ & $\begin{array}{c}0.003 \\
(1.168)\end{array}$ & $\begin{array}{c}0.001 \\
(2.879)\end{array}$ & 0.011 \\
\hline Hong Kong & $\begin{array}{c}-0.050 \\
(-3.148)\end{array}$ & $\begin{array}{c}-0.004 \\
(-0.139)\end{array}$ & $\begin{array}{c}-0.023 \\
(-3.419)\end{array}$ & $\begin{array}{c}0.007 \\
(7.224)\end{array}$ & 0.090 \\
\hline Spain & $\begin{array}{c}-0.006 \\
(-0.921)\end{array}$ & $\begin{array}{c}0.020 \\
(1.940)\end{array}$ & $\begin{array}{c}-0.004 \\
(-1.700)\end{array}$ & $\begin{array}{c}0.001 \\
(2.475)\end{array}$ & 0.019 \\
\hline Sweden & $\begin{array}{c}-0.008 \\
(-1.472)\end{array}$ & $\begin{array}{c}0.028 \\
(3.208)\end{array}$ & $\begin{array}{c}-0.004 \\
(-2.041)\end{array}$ & $\begin{array}{c}0.000 \\
(0.105)\end{array}$ & 0.013 \\
\hline Australia & $\begin{array}{c}-0.002 \\
(-0.235)\end{array}$ & $\begin{array}{c}0.025 \\
(2.104)\end{array}$ & $\begin{array}{c}-0.001 \\
(-0.307)\end{array}$ & $\begin{array}{c}0.001 \\
(2.180)\end{array}$ & 0.018 \\
\hline Italy & $\begin{array}{c}-0.012 \\
(-1.376)\end{array}$ & $\begin{array}{c}-0.007 \\
(-0.475)\end{array}$ & $\begin{array}{c}-0.001 \\
(-0.168)\end{array}$ & $\begin{array}{c}0.003 \\
(4.953)\end{array}$ & 0.024 \\
\hline
\end{tabular}


Table 10

Coefficients on the Unanticipated Trades in Exchange Traded Funds

The table shows the coefficients on the unanticipated trades of the foreign country ETFs $\left(v(x)_{t}^{\text {ETF }}\right)$ from the two latent factor model of international stock returns. The trades represent risk factors that are in addition to the two latent ("global") risk factors in the international equity pricing model. The model is estimated separately for each holding period $H$ by Generalized Method of Moments. The Newey-West $t$ statistics (in parentheses) are asymptotically robust to general forms of heteroskedasticity and autocorrelation. At the bottom of the table, the $\chi^{2}(12)$ statistics which test the joint significance of the unanticipated trades are presented along with their asymptotic marginal significance levels ( $P$-value).

\begin{tabular}{|c|c|c|c|}
\hline & $H=1 / 2$ hour & $H=1$ day & $H=5$ days \\
\hline & $\begin{array}{l}v(x)_{t}^{E T F} \\
(t \text {-stat. })\end{array}$ & $\begin{array}{l}v(x)_{t}^{E T F} \\
(t \text {-stat. })\end{array}$ & $\begin{array}{l}v(x)_{t}^{E T F} \\
(t \text {-stat. })\end{array}$ \\
\hline Germany & $\begin{array}{c}0.044 \\
(17.620)\end{array}$ & $\begin{array}{c}0.031 \\
(6.852)\end{array}$ & $\begin{array}{c}0.018 \\
(4.819)\end{array}$ \\
\hline Japan & $\begin{array}{c}0.026 \\
(26.410)\end{array}$ & $\begin{array}{c}0.034 \\
(9.816)\end{array}$ & $\begin{array}{c}0.042 \\
(7.393)\end{array}$ \\
\hline UK & $\begin{array}{c}0.058 \\
(29.269)\end{array}$ & $\begin{array}{c}0.024 \\
(4.132)\end{array}$ & $\begin{array}{c}-0.028 \\
(-4.070)\end{array}$ \\
\hline Switzerland & $\begin{array}{c}0.046 \\
(14.653)\end{array}$ & $\begin{array}{c}0.020 \\
(2.479)\end{array}$ & $\begin{array}{c}0.000 \\
(0.002)\end{array}$ \\
\hline Canada & $\begin{array}{c}0.096 \\
(17.274)\end{array}$ & $\begin{array}{c}0.095 \\
(7.015)\end{array}$ & $\begin{array}{c}0.022 \\
(1.226)\end{array}$ \\
\hline France & $\begin{array}{c}0.055 \\
(25.713)\end{array}$ & $\begin{array}{c}0.039 \\
(6.541)\end{array}$ & $\begin{array}{c}0.068 \\
(8.441)\end{array}$ \\
\hline Netherlands & $\begin{array}{c}0.027 \\
(9.183)\end{array}$ & $\begin{array}{c}-0.002 \\
(-0.175)\end{array}$ & $\begin{array}{c}-0.056 \\
(-4.382)\end{array}$ \\
\hline Hong Kong & $\begin{array}{c}0.070 \\
(24.749)\end{array}$ & $\begin{array}{c}0.088 \\
(8.702)\end{array}$ & $\begin{array}{c}0.052 \\
(4.651)\end{array}$ \\
\hline Spain & $\begin{array}{c}0.040 \\
(12.834)\end{array}$ & $\begin{array}{c}0.064 \\
(6.264)\end{array}$ & $\begin{array}{c}0.044 \\
(3.436)\end{array}$ \\
\hline Sweden & $\begin{array}{c}0.050 \\
(12.173)\end{array}$ & $\begin{array}{c}0.030 \\
(1.677)\end{array}$ & $\begin{array}{c}-0.005 \\
(-0.214)\end{array}$ \\
\hline Australia & $\begin{array}{c}0.069 \\
(20.831)\end{array}$ & $\begin{array}{c}0.057 \\
(5.088)\end{array}$ & $\begin{array}{c}0.008 \\
(0.610)\end{array}$ \\
\hline Italy & $\begin{array}{c}0.062 \\
(20.147)\end{array}$ & $\begin{array}{c}0.094 \\
(9.836)\end{array}$ & $\begin{array}{c}-0.010 \\
(-0.833)\end{array}$ \\
\hline $\begin{array}{l}\chi^{2}(12) \text { statistic } \\
P \text {-value }\end{array}$ & $\begin{array}{c}4152.87 \\
<0.001\end{array}$ & $\begin{array}{l}512.52 \\
<0.001\end{array}$ & $\begin{array}{l}193.51 \\
<0.001\end{array}$ \\
\hline
\end{tabular}


Table 11

OLS Regressions of Home-Currency Returns on Foreign Exchange Traded Funds on the Latent Factors

The top part of the table shows the OLS regression coefficients of the (log) change in the home-currency price of the foreign-country ETF over holding period $H$ on the latent factors from the international equity pricing model. The home currency price of the ETF is calculated using the foreign currency futures prices. The latent factors are the linear combinations of the global instruments given in Table 8. The Newey-West $t$ statistics (in parentheses) are asymptotically robust to general forms of heteroskedasticity and autocorrelation. The $R^{2}$ statistics are adjusted for degrees of freedom. The bottom part of the table shows the values of the asymptotic marginal significance levels ( $P$-values) associated with the $\chi^{2}$ statistics which test whether the indicated coefficient is equal to the value of the beta coefficient from the cross-sectional model that is shown in Table 7.

\begin{tabular}{|c|c|c|c|c|c|c|c|c|c|}
\hline \multirow{2}{*}{ OLS Regress } & \multicolumn{3}{|c|}{$H=1 / 2$ hour } & \multicolumn{3}{|c|}{$H=1$ day } & \multicolumn{3}{|c|}{$H=5$ days } \\
\hline & $\begin{array}{c}F(1) \\
(t \text {-stat. })\end{array}$ & $\begin{array}{c}F(2) \\
(t \text {-stat.) }\end{array}$ & $R^{2}$ & $\begin{array}{c}F(1) \\
(t \text {-stat. })\end{array}$ & $\begin{array}{c}F(2) \\
(t \text {-stat. })\end{array}$ & $R^{2}$ & $\begin{array}{c}F(1) \\
(t \text {-stat. })\end{array}$ & $\begin{array}{c}F(2) \\
(t \text {-stat. })\end{array}$ & $R^{2}$ \\
\hline Germany & $\begin{array}{c}0.892 \\
(1.903)\end{array}$ & $\begin{array}{c}1.283 \\
(2.141)\end{array}$ & 0.147 & $\begin{array}{c}0.088 \\
(0.069)\end{array}$ & $\begin{array}{c}2.308 \\
(0.876)\end{array}$ & 0.025 & $\begin{array}{c}1.674 \\
(2.073)\end{array}$ & $\begin{array}{c}-0.286 \\
(-0.180)\end{array}$ & 0.007 \\
\hline Japan & $\begin{array}{c}0.234 \\
(0.639)\end{array}$ & $\begin{array}{c}1.449 \\
(2.956)\end{array}$ & 0.057 & $\begin{array}{c}-0.023 \\
(-0.024)\end{array}$ & $\begin{array}{c}1.350 \\
(0.665)\end{array}$ & 0.007 & $\begin{array}{c}0.369 \\
(0.528)\end{array}$ & $\begin{array}{c}0.410 \\
(0.300)\end{array}$ & 0.000 \\
\hline UK & $\begin{array}{c}0.329 \\
(1.155)\end{array}$ & $\begin{array}{c}1.264 \\
(3.374)\end{array}$ & 0.071 & $\begin{array}{c}0.572 \\
(0.795)\end{array}$ & $\begin{array}{c}0.590 \\
(0.386)\end{array}$ & 0.020 & $\begin{array}{c}1.756 \\
(3.460)\end{array}$ & $\begin{array}{c}-1.637 \\
(-1.633)\end{array}$ & 0.004 \\
\hline Switzerland & $\begin{array}{c}0.253 \\
(0.732)\end{array}$ & $\begin{array}{c}1.994 \\
(4.400)\end{array}$ & 0.126 & $\begin{array}{c}0.481 \\
(0.526)\end{array}$ & $\begin{array}{c}0.686 \\
(0.358)\end{array}$ & 0.016 & $\begin{array}{c}1.683 \\
(2.293)\end{array}$ & $\begin{array}{c}-1.048 \\
(-0.732)\end{array}$ & 0.003 \\
\hline Canada & $\begin{array}{c}0.551 \\
(1.153)\end{array}$ & $\begin{array}{c}0.371 \\
(0.574)\end{array}$ & 0.033 & $\begin{array}{c}-1.986 \\
(-2.040)\end{array}$ & $\begin{array}{c}6.323 \\
(3.125)\end{array}$ & 0.024 & $\begin{array}{c}0.854 \\
(0.980)\end{array}$ & $\begin{array}{c}0.977 \\
(0.589)\end{array}$ & 0.015 \\
\hline \multicolumn{10}{|c|}{ Test of Equal Coefficients ( $P$-values) } \\
\hline & $\varphi_{1}=\beta_{1}$ & $\varphi_{2}=\beta_{2}$ & both & $\varphi_{1}=\beta_{1}$ & $\varphi_{2}=\beta_{2}$ & both & $\varphi_{1}=\beta_{1}$ & $\varphi_{2}=\beta_{2}$ & both \\
\hline Germany & 0.818 & 0.032 & $<0.001$ & 0.475 & 0.381 & 0.029 & 0.404 & 0.857 & 0.080 \\
\hline Japan & 0.523 & 0.360 & $<0.001$ & 0.981 & 0.863 & 0.133 & 0.598 & 0.666 & 0.845 \\
\hline UK & 0.561 & 0.048 & $<0.001$ & 0.721 & 0.837 & 0.175 & 0.130 & 0.405 & 0.067 \\
\hline Switzerland & 0.327 & 0.050 & $<0.001$ & 0.435 & 0.611 & 0.002 & 0.716 & 0.654 & 0.009 \\
\hline Canada & 0.896 & 0.801 & 0.822 & 0.432 & 0.469 & 0.536 & 0.870 & 0.992 & 0.793 \\
\hline
\end{tabular}

